\title{
TAXATION AND THE LIFE CYCLE
}

OF FIRMS

Andres Erosa and Beatriz González

Documentos de Trabajo N. 1943

\section{BANCODEESPAÑA}

Eurosistema

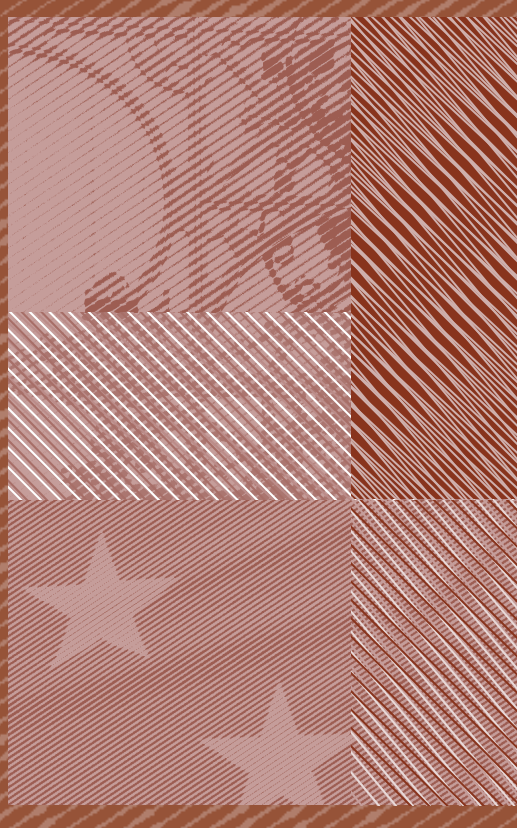


TAXATION AND THE LIFE CYCLE OF FIRMS 
TAXATION AND THE LIFE CYCLE OF FIRMS ${ }^{(*)}$

\section{Andrés Erosa}

UNIVERSIDAD CARLOS III DE MADRID

Beatriz González ${ }^{(*)}$

BANCO DE ESPAÑA AND UNIVERSIDAD CARLOS III DE MADRID

$\left.{ }^{\star}\right)$ This manuscript was prepared for the Carnegie-Rochester-NYU Conference Series on Public Policy, published in the Journal of Monetary Economics, Volume 105; August 2019 (https:// doi.org/10.1016/j.jmoneco.2019.04.006). (C) 2019. This manuscript version is made available under the CC-BYNC- ND 4.0 license http://creativecommons. org/licenses/by-nc-nd/4.0/.

(**) González gratefully acknowledges support from Fundación La Caixa (ID 100010434), grant number LCF/BQ ES15/10360005. The views expressed in this paper are those of the authors and do not necessarily represent the views of the Banco de España or the Eurosystem.

Documentos de Trabajo. N. ${ }^{\circ} 1943$

2019 
The Working Paper Series seeks to disseminate original research in economics and finance. All papers have been anonymously refereed. By publishing these papers, the Banco de España aims to contribute to economic analysis and, in particular, to knowledge of the Spanish economy and its international environment.

The opinions and analyses in the Working Paper Series are the responsibility of the authors and, therefore, do not necessarily coincide with those of the Banco de España or the Eurosystem.

The Banco de España disseminates its main reports and most of its publications via the Internet at the following website: http://www.bde.es.

Reproduction for educational and non-commercial purposes is permitted provided that the source is acknowledged.

(C) BANCO DE ESPAÑA, Madrid, 2019

ISSN: 1579-8666 (on line) 
Abstract

The Hopenhayn and Rogerson (1993) framework is extended to understand how different forms of taxing capital income affect firms' investment and financial policies over their life cycle. Corporate income taxation slows down firm growth over the life cycle by reducing after-tax profits available for reinvesting, and it distorts optimal firms' size. Dividend income taxation reduces external equity financing, but it does not affect size at maturity. Capital gains taxes make firms start larger, so that internal growth is lower. With these mechanisms in mind, we calibrate our economy to the US and discuss different revenue-neutral tax reforms that might lead to increases in aggregate output and capital.

Keywords: macroeconomics, capital income taxation, firm dynamics, investment.

JEL classification: D21, E22, E62, G32, H32. 


\section{Resumen}

En este trabajo extendemos el modelo de Hopenhayn y Rogerson (1993) para entender cómo distintos impuestos sobre capital afectan a las decisiones de inversión y de financiación de las empresas, así como a su ciclo de vida. El impuesto sobre sociedades ralentiza el crecimiento interno de las empresas, ya que estas tienen menos beneficios después de impuestos para reinvertir, y distorsiona su tamaño óptimo. El impuesto sobre los dividendos reduce la financiación a través de la emisión de acciones, pero no afecta a su tamaño en la madurez. El impuesto sobre las ganancias de capital hace que las empresas empiecen con un tamaño mayor para que el crecimiento interno sea menor. Teniendo en cuenta estos mecanismos, calibramos nuestra economía a Estados Unidos y discutimos reformas impositivas neutrales para el presupuesto del Gobierno que podrían incrementar la producción y el capital agregados.

Palabras clave: macroeconomía, impuestos sobre el capital, dinámica de empresas, inversión.

Códigos JEL: D21, E22, E62, G32, H32. 


\section{Introduction}

The macroeconomic effects of the taxation of capital income have received a great deal of attention by economists and policy makers. Throughout modern economies the taxation of capital income takes many different forms: capital gains taxation, interest income taxation, dividend taxation, and corporate income taxation. In particular, the tax rate on corporate income in the US was until recently among the highest of OECD countries, and this has raised concerns about its effects on job creation and investment. Policy advisors from the Obama and Trump administrations have advocated for changes in the taxation of capital income and, indeed, the Trump administration has recently cut by nearly half the corporate income tax rate. In this paper, we study how different forms of taxing capital income affect investment and financing decisions of firms over their life cycle, as well as the creation of new firms (firm entry), aggregate capital accumulation and output. We then evaluate the effects of a tax reform that eliminates the tax on corporate income and replaces the lost revenue with a common tax rate on all other form of capital income.

Corporate profits distributed as dividends suffer from the so-called 'double taxation', since they are taxed both at the corporate and the personal income level (by the corporate income tax and the dividend tax, respectively). The literature has long emphasized that corporate income taxation diminishes investment by firms by reducing the after tax return on capital. In this paper, we show that these distortions are much more severe when firms' growth over the life cycle is constrained by financial frictions. The impact of dividend taxation on firm investment decisions critically depends on the stage that firms are at in their life cycle, as young firms are more likely to issue equity while old firms are more likely to issue dividends. Young firms behave according to the 'traditional view' in the finance literature: an increase in dividend taxation raises the cost of external equity financing, negatively affecting firms' investment ${ }^{1}$. However, as emphasized by the 'new view' in the finance literature, dividend taxation does not affect investment decisions of firms distributing dividends (mature firms), since the dividend tax leads to an equiproportional reduction in the return and costs of investment. More generally, our paper stresses that the various ways capital income can be taxed (whether corporate income, dividend, or capital gains taxation) have quite different effects on investment and payout policies over the life cycle of firms, and hence on the life cycle growth of firms. They also have different and asymmetric effects on the market valuation of new versus incumbent firms, and thereby on firm entry.

Our paper is motivated by micro evidence on firm dynamics and the life cycle of firms. Haltiwanger et al. (2013) argue that start ups play a critical role for understanding US employment growth dynamics. The mass of firms entering the economy is large, most new businesses start as small but (conditional on survival) grow fast, and new entrants are important for understanding employment growth. Moreover, Hsieh and Klenow (2009) argue that the cross country differences in the life cycle growth of firms are important for

\footnotetext{
${ }^{1}$ See, for instance, (Auerbach, 2002) for a description of these views.
} 
understanding aggregate productivity differences across countries. The evidence indicates that firms face substantial equity issuance costs (see Hennessy and Whited (2007), Lee et al. (1996)). Using micro evidence from US and UK firms, Cloyne et al. (2018) show that financial frictions affect more strongly investment decisions of young firms than that of mature firms. Campbell et al. (2013) empirically document heterogeneous investment responses across young and mature firms after the reduction on shareholder taxes in the US in 2003. Becker et al. (2013) study many tax reforms on 25 countries over a 20 year period, finding that changes in payout taxes affect firms differently depending on their financial regime. Overall, this evidence points to the importance of modeling the life cycle of firms for assessing the effects of taxation. A model with a representative firm, as in the standard Neoclassical Growth Model, implicitly focuses on mature firms (i.e. those distributing dividends where the 'new view' holds), disregarding the evidence that investment responses to tax changes vary over the life cycle of firms. Moreover, the empirical findings of Haltiwanger et al. (2013) suggest that it is important to consider the impact of taxation on business entry.

We extend the Hopenhayn and Rogerson (1993) framework of firm dynamics to understand how different forms of taxing corporate income affect the life cycle of firms. We start by analysing a simple version of the model with a deterministic fixed level of productivity determined upon entry. Companies need to raise equity to set the firm up, starting their life in the 'traditional view' regime (equity issuance phase). They grow by accumulating profits (growing phase), until they reach their optimal size and start distributing dividends (maturity phase). Consistent with the 'new view', dividend taxation does not distort investment decisions and dividends paid by mature firms. However, dividend taxation diminishes the optimal amount of initial equity issued by firms. Intuitively, firms can diminish the taxes paid by financing a larger portion of investments with retained earnings. Hence, dividend taxation reduces the initial size of firms, retarding the age at which they reach maturity, and diminishes entry. The taxation of capital gains has the opposite effects of dividend taxation. First, the taxation of capital gains encourages firms to issue more equity at entry in order to avoid paying the taxes that would accrue with the accumulation of internal funds. Second, it distorts the optimal scale of the firm at maturity. Corporate income taxation impacts on capital accumulation through several channels. First, corporate income taxation distorts the optimal size and dividends paid by mature firms by decreasing the return on capital. Second, crucial to our analysis and results, the corporate income tax decreases after-tax earnings, making it harder for firms to finance investment with retained earnings and causing firms to grow at a slower pace over their life cycle. As a result, the market value of the firm decreases, leading to two additional effects of corporate income taxation on capital accumulation: firms raise less equity at entry, and the equilibrium mass of entry becomes smaller. While these effects are also present under dividend taxation, they are stronger under corporate income taxation.

The baseline economy with firm dynamics (due to idiosyncratic productivity shocks at the firm level) is calibrated to moments on the micro data on firms' investment and 
financing decisions. We use the calibrated model economy to quantitatively assess the effects of a reform that eliminates the taxation of corporate income while keeping constant the tax revenue collected on capital. This is done by finding the common tax rate $(\tau)$ on all forms of capital income (dividends $\tau_{d}$, interest income $\tau_{r}$, and capital gains $\tau_{g}$ ) that collects the same tax revenue as in the baseline economy. The purpose of the proposed policy reform is twofold. Firstly, all sources of capital income are treated symmetrically from the household perspective. Secondly, by eliminating the corporate income tax, financially constrained firms are able to accumulate profits and to reach maturity (the dividend distribution stage) faster. The elimination of the corporate income tax in the baseline economy $\left(\tau_{c}=0.34\right)$ should be accompanied by an increase in the other capital income tax rates to 0.41 in order to keep government revenue constant (the dividend and capital gains tax in the baseline economy were set to 0.15 and the interest income tax was set to 0.25 ). In equilibrium, this leads to an increase in the initial size at entry, a decrease in the optimal size at maturity, and a decrease in the time to reach maturity. This benefits mostly young firms, thereby increasing entry by $35 \%$. Aggregate output increases $12 \%$, accompanied by a large increase in the aggregate capital stock (32\%). Hence, the large response of firm entry is important for understanding the macroeconomic effects of the tax reform. When entry is kept fixed, the increase in output is a third and the rise in capital is half of those in the economy with endogenous entry.

At the heart of our results is the fact that the tax reform increases the expected value at entry more than the value of incumbent firms, leading to a reallocation of resources from mature to younger firms, which operates through an increase in entry and in the equilibrium wage rate. The elimination of corporate income taxation allows financially constrained firms to retain a larger fraction of their earnings and increase their investments. The ability to retain earnings is particularly relevant for young firms, which are more likely to be constrained than the average incumbent firm in the economy. Since the value at entry is determined by the average value of age- 0 firms, the value of the average firm entering the economy increases more than that of incumbent firms when corporate income taxation is eliminated. In general equilibrium, the increase in the value of entry requires the wage rate to rise, which reduces labor demand by incumbent firms. Labor market clearing requires a larger mass of firm entry, which rises by about 35\%. Larger firm entry, together with a reallocation of resources to financially constrained firms, lead to an increase in aggregate TFP of $4.6 \%$.

Our model economy builds on Gourio and Miao (2010), who study the impact of dividend taxation on firms' investment and payout decisions. We contribute by comparing alternative forms of capital income taxation and by extending their analysis to incorporate three key features for our results: life cycle (endogenous entry), financial frictions, and corporate income taxes. In particular, we emphasize the importance of the life cycle of firms for understanding how taxation affects investment incentives of firms. Korinek and Stiglitz (2009) build a theory of the life cycle of firms for understanding the impact of dividend taxation but abstract from corporate income taxation and firm entry. McGrattan and Prescott (2005) and Atesagaoglu (2012) study how corporate income taxation affects the market valuation 
of firms in environments with a representative firm. Conesa and Domínguez (2013) advocate for the elimination of corporate income taxation in a Ramsey optimal taxation exercise with a representative firm, with no financial frictions and no firm entry/exit. Similar to us, Anagnostopoulos et al. (2015) evaluate the gains of eliminating corporate income taxation in a model with firm heterogeneity and household heterogeneity. We abstract from household heterogeneity but contribute by focusing on firm entry and the life cycle of firms, which turn out to be key for the large quantitative effects of our tax reform, and which Haltiwanger et al. (2013) emphasize as crucial for understanding the dynamics of employment growth in the US. The financial crises has sparked great interest in the literature analyzing the role of financial frictions in business cycle fluctuations. Papers in this literature include Cooley and Quadrini (2001), Khan and Thomas (2013), Jermann and Quadrini (2012) (among many others). Our results suggest that the design of capital income taxation may affect the propagation of business cycle shocks.

An outline of the paper follows. Section 2 presents and analyzes a simple version of our baseline model economy in which firms do not face idiosyncratic shocks to their productivity, in order to illustrate how different forms of taxing capital income affect investment and payout policies over the life cycle of firms, the value of firms to its shareholders, and firm entry. Section 3 presents our baseline model economy of firm dynamics and taxation of capital income, and shows the calibration and our main quantitative exercises. Section 4 concludes ${ }^{2}$.

\section{A Simple Deterministic Model Economy}

Our baseline model extends the Hopenhayn and Rogerson (1993) framework of firm dynamics to study taxation of corporate capital income. Time is continuous ${ }^{3}$. Each firm may exit the economy with some fixed probability. The entry of new firms is endogenous. Firms can finance investment with retained profits or equity issuance. Firms face adjustment costs in capital. Following Cooley and Quadrini (2001) and Gomes (2001), firms face financial frictions, since equity issuance is costly. There is a representative household that owns all firms. There is a large number of firms so that the representative consumer does not face any uncertainty. As in Gourio and Miao (2010), households pay taxes on dividends $\left(\tau_{d}\right)$, interest income $\left(\tau_{r}\right)$, and capital gains taxes $\left(\tau_{g}\right)^{4}$. In addition, corporations pay taxes on corporate profits $\left(\tau_{c}\right)$, so that capital income is taxed both at the firm and household level.

\footnotetext{
${ }^{2}$ Online appendix D evaluates the sensitivity of the results to alternative formulations of entry decisions, the shock process faced by firms, and to incorporating an endogenous labor supply choice.

${ }^{3}$ Achdou et al. (2017) and Barczyk and Kredler (2014) advocate the use of continuous time models for analyzing heterogeneous agent models. We extend their methods to a model of firm dynamics with financial frictions.

${ }^{4}$ While in the US capital gains are taxed upon realization, we follow standard practice in the literature by modeling capital gains taxation on an accrual basis. This modeling choice simplifies the analysis considerable and allow us to derive our results in a more transparent way.
} 
In this section, we illustrate the key ideas of our paper in a deterministic version of our baseline model economy that abstracts from adjustment costs in capital.

\subsection{The problem of a firm}

When firms are created, they draw a productivity $z$ that stays fixed over the lifetime of a firm. Firms exit exogenously the economy at a rate $\delta_{d}$. The economy is a steady state with an after tax interest rate equal to $r\left(1-\tau_{r}\right)=\rho$, where $\rho$ is the rate of time preference of the representative household (investor).

Each firm produces output with a decreasing returns to scale production function in capital and labor inputs: $f(z, k, n)=z^{1-\alpha-\eta} k^{\alpha} n^{\eta}$. Profits are given by

$$
\pi(z, k)=\max _{n}\{f(z, k, n)-w n-\delta k\}
$$

The flow constraint is

$$
\dot{k}=\left(1-\tau_{c}\right) \pi(z, k)-d+(1-\xi) e
$$

where $d$ and $e$ denote dividend distribution and equity issued by firms. We assume that equity issuance is costly. There is a cost $\xi$ per unit of equity issued, so the resources available are $e(1-\xi)$.

Consider a firm with fixed $z$. The market value $(V)$, the dividends paid $(d)$, and the equity issued $(e)$ are deterministic functions of the age of the firm $t$. However, these variables are not explicitly indexed with a subscript $t$ to simplify the notation (unless there is some risk of confusing the reader). Taking as given investment and financial policies, the market value of the firm $V$ is such that the after tax rate of return on equity equals the investor rate of discount $\rho$ :

$$
\rho=\frac{d\left(1-\tau_{d}\right)+\left(1-\tau_{g}\right)\left(\dot{V}-e-\delta_{d} V\right)}{V}
$$

where $\dot{V}$ represents the rate of change of $V$ with respect to time (age of the firm). Note that increases in share values due to equity issuance are not taxable. Firm exit gives rise to negative capital losses that are tax deductible. The above non-arbitrage equation can be re-arranged as

$$
\left(\frac{\rho}{1-\tau_{g}}+\delta_{d}\right) V=\frac{1-\tau_{d}}{1-\tau_{g}} d-e+\dot{V}
$$

The solution to this first-order linear differential equation on $\mathrm{V}$ gives the integral in (2). Note that the path of dividends in this integral is multiplied by the ratio $\frac{1-\tau_{d}}{1-\tau_{g}}$, which follows from the interplay of two opposite effects of the taxation of dividends and capital gains. The numerator is explained by the fact that investors receive a fraction $1-\tau_{d}$ of the dividends 
distributed by the firm. The denominator is explained by the fact that when firms retain earnings (do not distribute dividends) the value of the firm increases and this capital gain is subject to the $\operatorname{tax} \tau_{g}$. In addition, the rate at which firms discount future dividends $\left(\frac{\rho}{1-\tau_{g}}+\delta_{d}\right)$ increases with the capital gains tax rate. Intuitively, dividend growth raises the value of the firm over time and these changes in market value are taxed at a rate $\tau_{g}$.

The problem of the firm in state $(z, k)$ is then to choose investment and financial policy to maximize:

$$
V(z, k) \equiv \max \int_{0}^{\infty} e^{-\left(\frac{\rho}{1-\tau_{g}}+\delta_{d}\right) t}\left\{\frac{1-\tau_{d}}{1-\tau_{g}} d-e\right\} d t
$$

subject to:

$$
\begin{aligned}
& \dot{k}=\left(1-\tau_{c}\right) \pi(z, k)-d+(1-\xi) e \\
& d \geq 0, e \geq 0, k_{0} \text { given. }
\end{aligned}
$$

Associate the present-value multipliers $e^{-\left(\frac{\rho}{1-\tau_{g}}+\delta_{d}\right)} \lambda_{t}$ to the flow of funds constraint, $e^{-\left(\frac{\rho}{1-\tau_{g}}+\delta_{d}\right)} \mu_{t}^{e}$ to the non-negativity constraint on equity issuance, and $e^{-\left(\frac{\rho}{1-\tau_{g}}+\delta_{d}\right)} \mu_{t}^{d}$ to the non-negativity on dividend distribution. Then, the FOC from the Maximum Principle imply:

$$
\begin{aligned}
& \lambda=\frac{1-\tau_{d}}{1-\tau_{g}}+\mu^{d} \\
& (1-\xi) \lambda+\mu^{e}=1 \\
& \lambda\left[\frac{\rho}{1-\tau_{g}}+\delta_{d}-\left(1-\tau_{c}\right) \pi^{\prime}(z, k)\right]=\dot{\lambda} \\
& \dot{k}=\left(1-\tau_{c}\right) \pi(z, k)-d+e(1-\xi) \\
& \mu^{d} \geq 0, d \geq 0, \mu_{t}^{d} d=0 \\
& \mu^{e} \geq 0, e \geq 0, \mu_{t}^{e} e=0 \\
& \lim _{t \rightarrow \infty} e^{-\left(\frac{\rho}{1-\tau_{g}}+\delta_{d}\right) t} \lambda_{t} k_{t}=0 \text { (Transversality) }
\end{aligned}
$$

Conditions (3) and (7) imply that the shadow value of funds $\lambda \geq \frac{1-\tau_{d}}{1-\tau_{g}}$, with equality if dividends are strictly positive. Conditions (4) and (8) imply that the shadow value of funds $\lambda \leq \frac{1}{1-\xi}$, with equality if equity issuance is strictly positive. In sum, the shadow value of funds satisfies $\lambda \in\left[\frac{1-\tau_{d}}{1-\tau_{g}}, \frac{1}{1-\xi}\right]$.

\subsection{Entry, optimal initial equity, and time to maturity}

As in Hopenhayn and Rogerson (1993), firms pay a fixed cost $c_{e}$ to draw a productivity $z$ from an exogenous probability density $g_{e}$. The firm decides the initial amount of capital $k_{0}(z)$ after observing the productivity draw $z$. The value of entry is then given by

$$
V^{e}=\int_{0}^{\infty} V\left(z, k_{0}(z)\right)-\frac{1}{1-\xi} k_{0}(z) g_{e}(z) d z=c_{e}
$$


where the second equality states that in a steady state equilibrium the value of entry should be equal to the entry cost. The wage rate adjusts to ensure that this is the case. The mass of firms entering the economy is determined by the labor market clearing condition:

$$
\begin{array}{r}
\int_{0}^{\infty} n(z, k) g(z, k) d z d k=1, \text { where } g \text { satisfies } \\
0=-\partial_{k}(s(z, k) g(z, k))-\delta_{d} g(z, k)+M g_{e}(z) I_{k=k_{0}(z)},
\end{array}
$$

where $n(z, k)$ denotes the optimal labor demand, $\dot{k}=s(z, k)$ is the optimal investment in capital, and $g(z, k)$ the mass of firms in state $(z, k)$.

Consider a firm with productivity $z$ that raises capital (equity) $k_{0}$ when newly created. The firm will accumulate capital until it reaches the optimal amount of capital $k^{*}(z)$. Once the firm reaches its optimal scale, it distributes dividends until it dies. The age $(\mathrm{T})$ at which the firm starts distributing dividends solves the following equation:

$$
\left(1-\tau_{c}\right) \int_{0}^{T} \pi\left(z, k_{t}\right) d t+k_{0}=k^{*}
$$

The above equation defines an implicit function $T\left(z, k_{0}\right)$ characterizing the age when a firm matures (starts distributing dividends) as a function of its net worth at entry (age 0). Since an increase in initial capital $k_{0}$ increases the profits accumulated by the firm over time, the firm takes a shorter period to reach maturity. Formally, differentiating (12) with respect to initial capital $k_{0}$ yields

$$
\frac{d T}{d k_{0}}=-\frac{1+\left(1-\tau_{c}\right) \int_{0}^{T} \pi^{\prime}\left(z, k_{t}\right) \frac{d k_{t}}{d k_{0}} d t}{\left(1-\tau_{c}\right) \pi\left(z, k_{T}\right)}<0
$$

In words, if initial capital $k_{0}$ is greater, everything else held constant, the time to reach maturity decreases.

We now focus on determining the optimal amount of initial equity. For a fixed value of $k_{0}, \mathrm{~T}$ is computed from (12). Equations (3)- (7) imply that the shadow value of funds at age $\mathrm{T}$ satisfies $\lambda(T)=\frac{1-\tau_{d}}{1-\tau_{g}}$. Integrating (5) between 0 and $T(k)$ gives

$$
\lambda(0)=\frac{1-\tau_{d}}{1-\tau_{g}} e^{\int_{0}^{T}\left[\left(1-\tau_{c}\right) \pi^{\prime}\left(z, k_{t}\right)-\left(\frac{\rho}{1-\tau_{g}}+\delta_{d}\right)\right] d t} .
$$

The function inside the integral in (14) has a positive sign for all $t<T$, is equal to 0 at $\mathrm{T}$, and is decreasing in $k_{0}$ (due to decreasing returns to capital accumulation). Moreover, $\mathrm{T}$ is a decreasing function of $k_{0}$. As a result, it is easy to see that $\lambda(0)$ is a decreasing function of $k_{0}$. The optimal value of initial equity is obtained by solving $\lambda(0)=1+\xi$.

The value of a firm with initial capital (equity) $k_{0}$ satisfies

$$
V\left(z, k_{0}\right)=\int_{T\left(k_{0}, z\right)}^{\infty} \frac{1-\tau_{d}}{1-\tau_{g}} e^{-\left(\frac{\rho}{1-\tau_{g}}+\delta_{d}\right) t} d^{*}(z) d t=\frac{1-\tau_{d}}{1-\tau_{g}} d^{*}(z) \frac{e^{-\left(\frac{\rho}{1-\tau_{g}}+\delta_{d}\right) T\left(z, k_{0}\right)}}{\frac{\rho}{1-\tau_{g}}+\delta_{d}} .
$$


Note that another way of solving for the optimal amount of initial equity is

$$
\max _{k_{0}} V\left(z, k_{0}\right)-\frac{1}{1-\xi} k_{0}
$$

which implies

$$
V^{\prime}\left(z, k_{0}\right)=\frac{1-\tau_{d}}{1-\tau_{g}} d^{*}(z) e^{-\left(\frac{\rho}{1-\tau_{g}}+\delta_{d}\right) T\left(z, k_{0}\right)}(-1) \frac{d T}{d k_{0}}=\frac{1}{1-\xi}
$$

Since $\mathrm{V}$ is a concave function of capital, it follows that the solution for initial equity is unique.

\subsection{The life cycle of a firm}

The previous discussion highlights that, as in Korinek and Stiglitz (2009), firms in our simple model face three distinct phases during their life cycle: equity issuance phase, growth phase, and dividend distribution phase.

- Equity issuance phase. The first stage occurs when firms are created. Firms start with zero net worth. In order to operate they need to raise equity at age 0 so that $e_{0}>0$. The Kuhn Tucker complementarity slackness condition (8) implies that $\mu_{0}^{e}=0$ so that (4) implies that the shadow value of assets at age 0 is given by $\lambda_{0}=\frac{1}{1-\xi}$. The non-negativity constraint on dividend distribution binds $\left(\mu_{0}^{d}>0\right)$ so that firms do not distribute dividends. The amount of initial equity raised is such that:

$$
\left(1-\tau_{c}\right) \pi^{\prime}\left(z, k_{0}\right)>\frac{\rho}{1-\tau_{g}}+\delta_{d}
$$

By equation (5), once the firm is set up and $\lambda_{0}=\frac{1}{1-\xi}$, the next instant the value of the multiplier is decreasing, i.e. $\lim _{t \rightarrow 0^{+}} \lambda_{t}<\frac{1}{1-\xi}$. Otherwise, condition (18) implies that $\lim _{t \rightarrow 0^{+}} \lambda_{t}>\frac{1}{1-\xi}$, which violates the non-negativity of $\mu_{t}^{e}$ (see equation (4)). This phase would fall within the so-called 'traditional view', where firms are using equity issuance as the marginal source of financing.

- Growth phase. When firms start operation (immediately after age 0), the continuity of $\lambda_{t}$ together with (18) imply that the shadow value of net worth decreases since $\left(1-\tau_{c}\right) \pi^{\prime}\left(z, k_{t}\right)>\frac{\rho}{1-\tau_{g}}+\delta_{d}$ for $t>0$ in the right neighborhood of $t=0\left(\dot{\lambda_{t}}\right)$. Newly created firms start operating and retain earnings in order to increase their capital. As capital grows, the shadow value of funds decreases, relaxing the non-negativity constraint on dividends (its multiplier decreases).

- Dividend distribution phase. Firms reach the dividend distribution phase (maturity) when the shadow value of funds reaches the value $\frac{1-\tau_{d}}{1-\tau_{g}}$. At this stage, the marginal source of funds is retained earnings, and its marginal cost equals the marginal benefit of 
distributing dividends. Growth ceases when firms reach a steady state with a constant capital $\left(k^{*}\right)$ and constant dividend distribution $d^{*}$ satisfying

$$
\begin{array}{r}
\left(1-\tau_{c}\right) \pi^{\prime}\left(z, k^{*}\right)=\frac{\rho}{1-\tau_{g}}+\delta_{d} \\
\left(1-\tau_{c}\right) \pi\left(z, k^{*}\right)=d^{*}
\end{array}
$$

\subsection{Discussion on taxation and the life cycle of firms.}

We now discuss, for a fixed wage rate, the effects of taxes on the life cycle of firms. Equations (19) and (20) determine the optimal level of capital $\left(k^{*}\right)$ and dividends $\left(d^{*}\right)$ by mature firms. The value of a mature firm with productivity $\mathrm{z}$ is

$$
V^{\text {mature }}(z)=\frac{1-\tau_{d}}{\rho+\delta_{d}\left(1-\tau_{g}\right)} d^{*}
$$

Using (15), the value of an age-0 firm with productivity $\mathrm{z}$ satisfies

$$
V^{\text {new }}(z)=\underbrace{\frac{1-\tau_{d}}{\rho+\delta_{d}\left(1-\tau_{g}\right)} d^{*}}_{V^{\text {mature }}(z)} e^{-\left(\frac{\rho}{1-\tau_{g}}+\delta_{d}\right) T\left(z, k_{0}\right)}
$$

The value of a new firm is a fraction of the value of a mature firm and that fraction decreases with the time it takes to reach maturity. Below we use (19)-(22) to evaluate the impact of capital income taxation on mature firms and on the market value of mature firms relative to that of age-0 firms.

Dividend taxation $\left(\tau_{d}\right)$ The tax rate on dividend distribution does not affect equations (19) and (20). It is then immediate that dividend taxation has no impact on capital and dividends paid by mature firms, a result consistent with the "new view" of the public finance literature. When the firm is indifferent between using its marginal unit of funds as dividend or investment, a change in the dividend tax rate has proportional effects on the benefits and cost of investment. As a result, investment decisions and dividend payouts of mature firms are unaffected by the dividend tax rate. However, the dividend tax reduces the market value of mature firms (it changes proportionally with the term $1-\tau_{d}$, as shown in (21)).

Paradoxically, the dividend tax rate affects capital accumulation when firms are not paying dividends. This is because the lower value of the firm to shareholders reduces the optimal amount of initial equity (see equation (17)), retarding the age at which firms reach maturity. Intuitively, the firm can effectively diminish the taxes paid by reducing (initial) equity issuance and by financing investment with retained earnings. The fact that the firm reaches maturity at a later age, implies that dividend tax rate decreases the market value of firms at entry more than at maturity (in (22) the increase in $\mathrm{T}$ caused by dividend taxation further reduces the value of entry). 
In sum, while dividend taxation does not distort the optimal scale and payouts of mature firms, it distorts the initial scale of operation of firms, diminishing capital accumulation along the life cycle and the age at which firms reach maturity. Moreover, dividend taxation affects assymmetrically the market value of mature firms versus that of entrants which, in general equilibrium, will negatively affect the creation of businesses (entry).

Taxation of capital gains $\left(\tau_{g}\right)$ The taxation of capital gains $\left(\tau_{g}\right)$ increases the cost of equity financing $\left(\frac{\rho}{1-\tau_{g}}\right)$, reducing capital and dividend distribution of mature firms (see equations (19) and (20)). The decrease in dividends implies a decrease in the market value of mature and young firms ${ }^{5}$. The capital gains tax has two opposite effects on the initial capital of firms. On the one hand, when capital gains tax increases, the return on holding firms' shares needs to increase to satisfy the non-arbitrage condition. Since technology features decreasing returns, this is attained by reducing the optimal size of the firm. This, in turn, reduces the optimal initial size. On the other hand, the capital gains tax stimulates equity issuance at entry by increasing the rate at which future dividends are discounted (note that $\frac{\rho}{1-\tau_{g}}+\delta_{d}$ increases with $\tau_{g}$ ). Intuitively, by raising more equity at entry, firms avoid paying taxes on capital gains that would accrue with the accumulation of internal funds. Note that this result is the opposite of what we found for dividend taxation. ${ }^{6}$

Corporate income taxation $\left(\tau_{c}\right)$ Corporate income taxation reduces capital accumulation and dividends paid by firms. Intuitively, corporate income taxation reduces the after tax benefit to capital (see left hand side of equation (19)) but without reducing the cost of funds to the firm. This effect reduces the optimal size $\left(k^{*}\right.$ decreases $)$ and distributions $\left(d^{*}\right)$ by mature firms (see equation (20)). Lower dividends imply a decrease in the market value of mature firms (see equation (15)) which, in turn, decreases the optimal amount of initial equity (equation (17)). Hence, firms start their life with a smaller scale. Moreover, the firm grows at a slower pace since the corporate income tax reduces the fraction of earnings that the firm accumulates during its growth phase in the life cycle (see equation (12)). The time to reach maturity may increase or not with corporate income taxation since there are two opposite forces at work: while firms grow more slowly, their optimal scale is smaller. In our computational experiments, the first effect is stronger so that firms take a longer time to mature.

It is important to note that the decrease in $d^{*}$ associated with corporate income taxation reduces proportionally the market value of firms at entry and at maturity. In addition,

\footnotetext{
${ }^{5}$ Note that $\tau_{g}$ enters in the denominator of (21). This expression represents the fact that the market value of mature firms increase with $\tau_{g}$ because the tax code in our model economy allows for a tax credit associated to the death of the firm. Quantitatively, this effect will likely have a small effect on the market value of firms if the death rate is small. As a result, we should expect the market value of mature firms to move together with $d^{*}$. This is always the case if we assume that there is no tax credit associated to the capital losses upon death of firms.

${ }^{6}$ Recall that, in order to minimize taxes on dividends, dividend taxation encourages young firms to finance investment with internal funds.
} 
for a fixed amount of initial equity, the corporate income tax makes it harder for firms to accumulate retained earnings, retarding the age at which firms reach maturity. This additional effect implies that corporate income taxation affects more negatively the market value of firms at entry than at maturity. The asymmetric effect on market valuations at entry and at maturity implies that the corporate income tax discourages entry, an effect that will play an important role in the tax reform, and that is analyzed in the next section of the paper.

Quantitative illustration We parameterize the simple model in order to illustrate the discussion on how various forms of taxing capital income affect the life cycle of firms ${ }^{7}$. We simulate in partial equilibrium (e.g. fixed wage rate) the life cycle of a firm in three different scenarios: under the baseline parametrization, and after an increase of 5 percentage points in each of the tax rates, maintaining everything else constant. Figure 1 plots the life cycle profile of capital for the four cases considered. Consistent with our discussion above, firms start their life cycle with a lower amount of capital when they are subject to dividend or corporate income taxation. The initial level of capital is slightly lower under dividend taxation than under corporate income taxation. While the level of capital at maturity is not affected by dividend taxation, it is negatively affected by corporate income taxation. This is the key factor explaining why it takes the firm about one more year to reach maturity under dividend taxation, despite the fact that the firm is able to accumulate capital faster under

Figure 1: The Life Cycle of a Firm

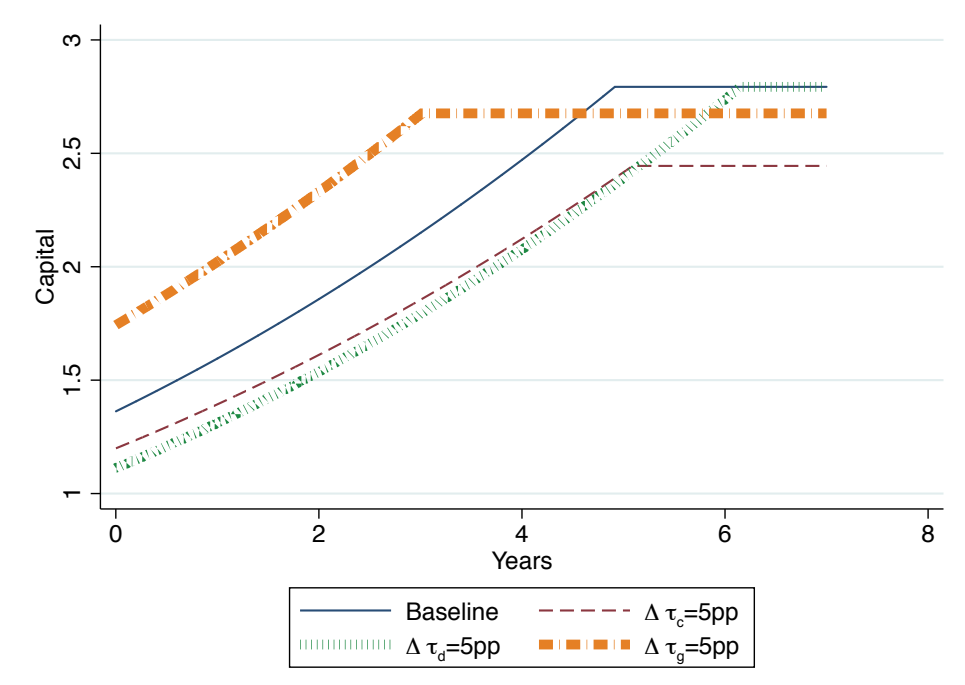

\footnotetext{
Life cycle of three identical firms in equilibriums with different taxes. Blue is the baseline: $\tau_{c}=0.34, \tau_{d}=0.15, \tau_{g}=0.15$ and $\tau_{r}=0.25$. Changes after an increase of 5 pp of each of the tax rates, maintaining everything else constant.
}

\footnotetext{
${ }^{7}$ We set the following parameters for the production function $\alpha=0.3 \times 0.85, \eta=0.7 \times 0.85$. The depreciation of capital is fixed as $\delta=0.05$ and the rate of time preference is set so that the steady state interest rate is $4 \%(r=0.04)$. The equity issuance cost is set to 0.10 . The wage rate is fixed at 1 . Taxes in baseline are $\tau_{c}=0.34, \tau_{d}=0.15, \tau_{g}=0.15$ and $\tau_{r}=0.25$
} 
dividend taxation than under corporate income taxation. The latter explains why the age profile of capital in the figure is steeper under dividend taxation than corporate taxation.

It is interesting to compare the effects of dividend taxation with those of capital gains taxation. While dividend taxation does not distort capital accumulation of mature firms, it has a large negative impact on the initial amount of equity at entry. In this way, the firm finances a larger portion of its investment over the life cycle with internal funds, diminishing the present value of taxes paid on dividends. Capital gains taxation does precisely the opposite. It encourages firms to finance a bigger fraction of their investment with external equity, diminishing firm growth over the life cycle, and the present value of taxes paid on capital gains. In terms of capital accumulation, the trade-off is between distorting investments prior to becoming mature (dividend taxation) versus distorting the optimal scale at maturity (capital gains taxation). The corporate income tax distorts investment decisions all through the life cycle.

\section{The Stochastic Model Economy}

The simple model is extended as follows. Following the standard theory of investment, we introduce adjustment costs in capital and uncertainty in productivity. Physical capital evolves according to

$$
\dot{k}=x-\delta k \text {. }
$$

and the resource cost of investing $x$ is given by $x+\Psi \frac{x^{2}}{2 k}$, where the second term reflects the presence of adjustment costs in capital.

The productivity of a firm $(z)$ follows a geometric Brownian Motion

$$
d z=\mu z d t+\sigma z d W
$$

where $\mu$ determines the drift and $d W$ is a Wiener process. Since productivity follows a geometric Brownian motion, large firms in our model follow Gibrat's Law and growth rates are independent of firm size. Empirical research, such as Hall (1987), suggests that Gibrat's Law is a good approximation for firms that are not too small (see also Gabaix (2009)). Similar specification of the productivity shocks has been widely used in the literature on firm dynamics (see Atkeson and Kehoe (2005), Luttmer (2007), Da-Rocha et al. (2017), among many others $)^{8}$.

The flow of a firm at time $t$ in state $(z, k)$ with investing expenditures $x$ is given by

$$
\begin{aligned}
& d-e(1-\xi)=\left(1-\tau_{c}\right) \pi(z, k)-x-\Psi_{k} \frac{x^{2}}{2 k}, \\
& \text { where } \\
& \pi(z, k)=\max _{n}\{y(z, k, n)-w n\} .
\end{aligned}
$$

\footnotetext{
${ }^{8}$ Nonetheless, in online appendix D.3 of the paper we consider the robustness of our results to an alternative specification in which productivity follows an autoregressive process.
} 
The firm in state $(z, k)$ solves the following optimal control problem:

$$
\begin{aligned}
& v(z, k)=\max E_{0} \int_{0}^{\infty}\left\{\frac{1-\tau_{d}}{1-\tau_{g}} d-e\right\} e^{-\left(\frac{\rho}{1-\tau_{g}}+\delta_{d}\right) t} d t \\
& \text { subject to: } \\
& d z=\mu z d t+\sigma z d W \\
& \dot{k}=x-\delta k \\
& d-e(1-\xi)=\left(1-\tau_{c}\right) \pi(z, k)-x-\Psi_{k} \frac{x^{2}}{2 k}+\tau_{c} \delta k,
\end{aligned}
$$

where $\frac{\rho}{1-\tau_{g}}+\delta_{d}$ is the rate at which the firm discount future payments to/from shareholders when acting in their interest (see online appendix A).

The Hamiltonian-Jacobi-Bellman equation of a firm satisfies:

$$
\left(\frac{\rho}{1-\tau_{g}}+\delta_{d}\right) v(z, k)=\max \frac{1-\tau_{d}}{1-\tau_{g}} d-e+\partial_{k} v(z, k) \dot{k}+\mu z \partial_{z} v(z, k)+\frac{(z \sigma)^{2}}{2} \partial_{z z} v(z, k) .
$$

Upon entry, firms draw the initial productivity $z_{0}$ from a Pareto distribution:

$$
g_{e}\left(z_{0}\right)=\left\{\begin{array}{l}
\epsilon \frac{1}{z_{0}^{\epsilon+1}} \text { if } z_{0}>1 \\
0 \text { otherwise }
\end{array}\right.
$$

The initial amount of equity raised by a firm that draws $z$ solves the following problem:

$$
\hat{k}_{0}\left(z_{0}\right)=k_{0}\left\{v\left(z_{0}, k_{0}\right)-\frac{1}{(1-\xi)} k_{0}\right\}
$$

Then, the value of entry for a firm that draws $z$ can be expressed as

$$
v^{e}\left(z_{0}\right)=v\left(z_{0}, \hat{k}_{0}\left(z_{0}\right)\right)-\frac{1}{(1-\xi)} \hat{k}_{0}
$$

In equilibrium the free entry condition requires

$$
V^{e} \equiv \int_{1}^{\infty} v^{e}\left(z_{0}\right) g^{e}\left(z_{0}\right) d z_{0}=\int_{1}^{\infty} v^{e}\left(z_{0}\right) \epsilon \frac{1}{z_{0}^{\epsilon+1}} \leq c_{e}
$$

with strict equality if there is positive entry.

The distribution of firms depends on firms investment and entry decisions. The measure $g$ of firms in state $(z, k)$ satisfies:

$$
0=-\partial_{k}(s(z, k) g(z, k))-\partial_{z}(\mu z g(z, k))+\frac{(z \sigma)^{2}}{2} \partial_{z z} g(z, k)-\delta_{d} g(z, k)+M g_{e}(z) I_{k=k_{0}(z)},
$$

where $s(z, k)=\dot{k}=x-\delta k$ and $\mathrm{M}$ denotes the mass of firms entering the economy. 
In the presence of uncertainty, shocks to firms' productivity may change their financial regimes over the life cycle. A firm that is increasing its capital and issuing equity, may stop doing so if productivity decreases. When productivity decreases by a large amount, the firm may even start distributing dividends and disinvesting. Conversely, an increase in productivity may move the firm back to the equity issuance and investment regime. Online appendix $\mathrm{C}$ provides a detailed discussion on firms' investment and financial policies in the presence of uncertainty and adjustment costs.

There is a representative household that owns the market portfolio of firms. Households supply labor to firms, receive dividends, buy/sell shares of firms, and trade bonds. Since households do not face uncertainty on their savings, in equilibrium there is a no arbitrage condition (see online appendix A for its derivation) that equates the after-tax return in bonds to the expected after-tax return in each firm. Households pay personal income taxes on earnings $\left(\tau_{w}\right)$ and interest income on bonds $\left(\tau_{r}\right)$. The government rebates the aggregate tax revenue to the representative household with a lump sum transfer $(T)$.

The representative household maximizes the discounted lifetime utility subject to the intertemporal budget constraint

$$
\begin{aligned}
& \max _{\left\{c_{t}\right\}} \int_{0}^{\infty} e^{-\rho t} u\left(c_{t}\right) d t \\
& \text { subject to: } \\
& \int_{0}^{\infty} e^{-r\left(1-\tau_{r}\right) t}\left(c-\left(1-\tau_{w}\right) w-T\right)=a_{0}, \\
& a_{0}=\int v(z, k) g(z, k) d z d k,
\end{aligned}
$$

where $a_{0}$ is the period- 0 market value of all firms. In steady state equilibrium, $r_{t}\left(1-\tau_{r}\right)=\rho$ and $c_{t}=c \forall t$. Note that given that firms cannot borrow, the assumption of a representative consumer implies that bonds are in zero net supply $b_{0}=0$ and households make zero interest income ${ }^{9}$.

Definition of steady state equilibrium Given a fiscal policy $\left(\tau_{w}, \tau_{r}, \tau_{c}, \tau_{g}, T\right)$, a steady state equilibrium is given by value functions for incumbent firms $(v(z, k))$, value of entry $V^{e}$, prices $(w, r)$, firms policy functions on employment $(n)$, investment in physical $(x)$ and financial policies $(d, e)$, initial equity $k_{0}$, mass of entry $M$, measure of firms $g(z, k)$, consumption $c$ and initial household assets $a_{0}$ such that:

1. Given prices, the value function $v(z, k)$ satisfies the HJB equation of the firm and firm decisions $(n, x, d, e)$ are optimal.

2. $V^{e}$ satisfies the free entry condition (33).

\footnotetext{
${ }^{9}$ Online appendix D.2 evaluates the sensitivity of the results when an endogenous labor labor supply choice is modeled.
} 
3. The government budget constraint is satisfied (all tax revenue is rebated back to consumers as a lump sum transfer).

4. Households maximize utility taking as given government transfer, prices, and initial wealth, which implies that steady state consumption is equal to permanent income: $c=\rho a_{0}+w+T$.

5. Labor, bonds, and goods market clear

$$
\begin{aligned}
& \int n(z, k) g(z, k) d z d k=1 \\
& c+c_{e} M+\int\left[x+\psi \frac{x^{2}}{k}\right] g(z, k) d z d k=\int z^{1-\alpha-\eta} k^{\alpha} n^{\eta} g(z, k) d z d k
\end{aligned}
$$

\subsection{Quantitative Analysis}

\subsubsection{Calibration}

The calibration targets aggregate and firm level data from the US economy. In principle, our goal is to target all US businesses that pay corporate income taxes. The calibration requires targeting "dynamic moments" from US firms, such as average firm growth, volatility and autocorrelation of investment rates over time. We follow Gourio and Miao (2010) in using Compustat data to pin down these calibration targets. Hence, the calibration strategy implicitly assumes that privately held businesses and publicly traded companies are alike with regards to employment growth, investment rates, and equity issuance by privately held businesses. The key difficulty is that there is very limited longitudinal data on private corporations. However, Haltiwanger (2006) provides evidence that both private and public firms face a life cycle in which net employment growth tends to be higher for young firms than mature firms even when controlling for firm size. Moreover, Asker et al. (2011) analyze a new data set on private US firms and find that firm growth, investment, return on assets are similar across private firms in this database and public firms in Compustat. To the extent that private corporations face a higher cost of external financing, the former type of firms should gain more than the latter from reducing corporate income taxes.

We also target cross-sectional data on the size distribution of businesses from the US Census Bureau. Now, the universe of US businesses include private pass-through businesses that are not subject to the US corporate income tax (S corporations, partnerships). ${ }^{10}$ Since most of these businesses tend to be small, as a compromise we target data on the size distribution of businesses that includes businesses with more than 50 employees. The set of parameters to be calibrated is divided in two groups.

\footnotetext{
${ }^{10}$ Developing a theory of organizational choice (pass through entities versus $\mathrm{C}$ corporations) is outside the scope of the current paper. See Dyrda and Pugsley (2018) for a theory of organizational choice.
} 
Parameters assigned without solving the model. The tax parameters are from the Internal Revenue Service (year 2015). The corporate income tax rate is $34 \%\left(\tau_{c}=0.34\right)^{11}$. The capital gains tax rate is set to $0.15\left(\tau_{g}=0.15\right)$, the dividend tax rate to $0.15\left(\tau_{d}=0.15\right)$, and the personal income tax rate to $0.25\left(\tau_{r}=0.25, \tau_{w}=0.25^{12}\right)$, which corresponds to the marginal Federal taxes faced by a married couple with the average household income in the US. Households are assumed to discount future utility at an annual rate of 0.0375 ( $\rho=0.0375)$ so that the (before tax) steady state return on capital is $5 \%$, consistent with the estimates of the return on capital by Cooley and Prescott (1995). The parameters on the production function are set to standard values in the literature: the profit share is set to 0.15 , with $70 \%$ of the remaining share going to labor and $30 \%$ to capital ( $\alpha=$ $0.85 * 0.3, \eta=0.85 * 0.7)$, as in Midrigan and $\mathrm{Xu}$ (2014). The depreciation rate of capital is set at 0.05 per year $\left(\delta_{k}=0.05\right)$. Based on data from US Census Bureau's Business Dynamic Statistics (BDS), the average annual exit rate of firms with more than 50 employees is $4.6 \%$, so $\delta_{d}=0.046$. Using data from Thomson Reuter's Securities Data Company (SDC) Platinum, we find that during the period 1995-2015 the total costs of equity issuance as a percentage of proceeds is about $7 \%^{13}$. This is computed following closely the procedure of Lee et al. (1996) for IPO firms. It is somewhat smaller than the ones reported by Hennessy and Whited (2007), who estimated equity issuance cost in the range of $8.3 \%$ to $10.1 \%$. Hence, the cost of raising external funds is set to $0.07(\xi=0.07)$. Nonetheless, firms raising their initial capital at entry face a higher equity issuance cost $\xi_{e}$. This parameter will be determined later by simulating the model economy. Our calibration requires that $\xi_{e}>0.07$ in order to match the equity issuance by incumbent firms.

Parameters assigned by solving the model. It remains to assign the parameters driving the stochastic process on productivity $\left(\mu_{z}, \sigma_{z}\right)$, the parameter $\Psi$ driving adjustment costs, the productivity distribution of firms that enter the economy and their cost of raising external capital. Entering firms draw their initial productivity from a Pareto distribution with tail parameter $\eta_{p}$ and a location parameter 1 (the lowest possible productivity is one). The wage rate is normalized to 1 , and the fixed cost of entry is set equal to the value of entry.

Targeted moments. Although the endogenous equilibrium outcomes of interest will be jointly determined by all of these parameters, each of these parameters is intuitively connected with a particular moment of interest. The parameter $\mu_{z}$ is closely connected with firm growth and $\sigma_{z}$ with the variance of investment. The parameter $\Psi$ is closely related to the correlation of investment rates across two consecutive years and the parameter determining the Pareto tail with the size distribution of businesses. Finally, the cost of raising initial

\footnotetext{
${ }^{11}$ The progressive rate structure of the federal corporate tax in the US is designed such that it produces a flat $34 \%$ tax rate on incomes from $\$ 335,000$ to $\$ 10,000,000$, gradually increasing to a flat rate of $35 \%$ on incomes above.

${ }^{12}$ Labor income tax rate is kept constant in all experiments.

${ }^{13}$ See online appendix B.2 for more details on the data and computation.
} 
equity is closely connected to the amount of external finance by incumbent firms. With these connections in mind, the following statistics are targeted:

1. An average annual employment growth of $2.1 \%$.

2. The volatility of the investment rate $(\mathrm{x} / \mathrm{k})$ among firms of 0.059 .

3. The autocorrelation of investment rates between two consecutive years of 0.57 .

4. The ratio of equity issuance by incumbent firms to investment of $12.6 \%$.

5. The size distribution of businesses, computed using data from BDS and reported in Table 2.

The first 4 targets are computed using Compustat data from over the period 19952015. ${ }^{14}$ For the reasons previously discussed, in computing the size distribution of businesses we abstracted from small businesses in the BDS and focused on businesses with more that 50 employees. Tables 1 and 2 show the parameter values and the calibration results.

Table 1: Calibration Baseline Economy

\begin{tabular}{ccc}
\hline Parameter & Description & Value \\
\hline$\psi$ & Capital adjustment cost & 0.09 \\
$\mu_{z}$ & Productivity drift & -0.00325 \\
$\sigma$ & Volatility of prod. shock & 0.15 \\
$\xi_{e}$ & Financing cost at entry & 0.30 \\
$\eta_{p}$ & Distribution of businesses & 1 \\
\hline
\end{tabular}

Parameter values and discussion. The model accounts well for the targeted moments. The baseline economy matches the average employment growth of 2.1 percent in the data. Recall that productivity in our model economy follows a geometric Brownian Motion with a drift given by $\mu=\mu_{z}+{\frac{\sigma_{z}^{2}}{2}}^{2}$. Hence, the variance of shocks is a force driving firm growth. ${ }^{16}$ The model economy accounts for the $2.1 \%$ in average employment growth with $\mu_{z}=-0.00325$. To measure the volatility of the investment rate and its autocorrelation over time in our baseline economy, we first solve the model to compute the stationary distribution of firms. Then, we draw firms from this distribution and simulate them over the year to compute annual investment rates. The annual volatility of the investment rate in the baseline economy is 0.054 , which is close to the value of 0.059 in the data. Matching this target requires a significant variance in productivity since $\sigma_{z}=0.15^{17}$. The parame-

\footnotetext{
${ }^{14}$ See online appendix B.1 for more information about the data and variable construction.

${ }^{15}$ This follows from Ito's lemma, and the specification of the process of productivity growth in our model, i.e. $d \ln z=\mu_{z} d t+\sigma_{z} d W$

${ }^{16}$ Moreover, the distribution of productivity at entry is such that most businesses in our baseline economy start their life with a low productivity level, not far from the minimum value of 1 , which represents a low barrier on $\mathrm{z}$.

${ }^{17}$ Nonetheless, recall that $z$ in the production function is raised to the power of 0.15 so that the variance of TFP is much smaller than the one in z. For instance, Gourio and Miao (2010) estimate a variance in TFP of 0.2 , though in their model TFP follows an autoregressive process with persistence of about 0.8
} 
Table 2: Calibration Results

\begin{tabular}{lcc}
\hline & Data & Model \\
\hline Target & & \\
\hline Avg. employment growth & 0.02 & 0.02 \\
Volatility investment rate & 0.059 & 0.054 \\
Autocorrelation invest. rate & 0.57 & 0.59 \\
Eq. issuance incumbents/investment & 0.13 & 0.13 \\
& & \\
Size Distribution of Businesses & & \\
\hline No. of Employees & Fraction Data & Fraction Model \\
{$[50,99)$} & 0.53 & 0.50 \\
{$[100,249)$} & 0.29 & 0.22 \\
{$[250,499)$} & 0.089 & 0.13 \\
{$[500,999)$} & 0.0429 & 0.07 \\
{$[1000,2499)$} & 0.0265 & 0.047 \\
{$[2500,4999)$} & 0.0099 & 0.018 \\
{$[5000, \infty)$} & 0.0115 & 0.0057 \\
\hline
\end{tabular}

Targeted moments in the data, and their respective counterpart in the model. Data comes from Compustat, and BDS for the size distribution of businesses.

ter $\psi=0.07$ is set to match the autocorrelation of annual investment rates over two years across the stationary distribution of firms. This parameter is between the 0.049 estimated by Cooper and Haltiwanger (2006) and the 1.08 value obtained by Gourio and Miao (2010). The size distribution of businesses in the baseline economy is determined by the distribution of businesses at entry and by the stochastic growth in productivity over the life cycle of firms. The model accounts reasonably well for the size distribution of businesses, although the match is not perfect. The model implies that 50 percent of businesses have fewer than 100 workers, and 22 percent of businesses employed between 100 workers and 250 workers. The corresponding fractions in the data are $53 \%$ and $29 \%$. The fraction of businesses with more than 5,000 employees are about $0.6 \%$ in the model economy and $1 \%$ in the data ${ }^{18}$.

A crucial parameter in our model economy is given by the cost of external financing. As in Korinek and Stiglitz (2009), financial frictions matter for the different financial regimes that firms go through their life cycle ${ }^{19}$. In particular, we want our model economy to be consistent with data on firm growth, investment rates, and the fraction of investment financed by raising capital on the equity market. Recall that the cost of external finance was set exogenously at 7 percent using data from SDC Platinum. The model economy matches the 13 percent target for the fraction of investment financed by equity issuance among incumbent firms. To match this statistic, the model requires that firms at entry face substantial financial

\footnotetext{
${ }^{18}$ In the data, most large firms are multi-establishment, a fact that our model cannot account for. This is the main reason our model underpredicts mass in largest size category.

${ }^{19}$ Gourio and Miao (2010)'s model abstracts from financial frictions and life cycle. Firms in their model go through different financial regimes because of the differential tax treatment on dividends and capital gains during the year 2003.
} 
frictions. The baseline economy assumes that when firms enter the economy they face equity issuance costs of 0.30 . Lower values of equity issuance costs at entry imply that firms raise a substantial amount of equity when they enter in order to invest a large amount and avoid adjustment costs in capital as they grow (in expectations) over their life cycle. While we do not have data on the cost of raising external funds when firms are created, we find that the cost of raising external funds in initial public offerings in the SDC data is about $12 \%$. Presumably, the cost of raising external funds when businesses are actually created should be much larger. Moreover, our model assumes that firms learn their productivity before making the initial investment in capital. Firms in our model would invest less when they enter if they face some uncertainty on their initial productivity and learn it over time. Hence, our calibrated equity issuance cost at entry may be capturing the effects of information frictions that our model abstracts from.

Table 3: Non-targeted Moments

\begin{tabular}{lcc}
\hline Variable & Data & Model \\
\hline Investment rate & 0.086 & 0.096 \\
Dividends/Earnings & 0.098 & 0.45 \\
Agg. eq. issuance/ agg. investment & 0.15 & 0.19 \\
Eq issuance entrants/agg. investment & 0.037 & 0.067 \\
\hline
\end{tabular}

Non-targeted moments in the data, and their respective counterpart in the model. Data moments from Compustat.

Other non-targeted moments. The aggregate investment rate $(x / k)$ in the model economy is 0.096 , somewhat above the 0.086 value from the National Income Accounts. The model economy overstates the ratio of aggregate dividends to aggregate earnings in Compustat (0.45 versus 0.098$)$. This also happens in the model by Gourio and Miao (2010). Perhaps this should not be surprising since both model economies abstract from share repurchases, which is another way of dividend distribution. The model does a decent job in matching the ratio of aggregate equity issuance to aggregate investment in the data ( 0.15 versus 0.19$)$. Moreover, the share of equity issuance by entrants relative to aggregate investment is 0.037 in the data and 0.067 in the model. ${ }^{20}$

In Figure 2, we plot age profiles of employment growth by firms ${ }^{21}$ in the model and the data. Although it is an untargeted moment, the model captures quite well the sharp decline in employment growth as firms age. In our model economy young firms are small and constrained, so they grow fast at the beginning. As they age and accumulate internal

\footnotetext{
${ }^{20}$ To measure the share of equity issuance by new entrants and by incumbents in Compustat, we add up the equity issuance of all firms that report doing an IPO in that same year on one side, and the rest of the firms operating in that year on the other, and divide both by the sum of investment in capital expenditures of all firms.

${ }^{21}$ Unfortunately, age is not a variable available in Compustat, so we construct a proxy with the available data, and define age as years since their IPO.
} 
funds, they are likely to become less constrained and progressively reach their optimal size. As a result, the age-profile of employment growth of firms is expected to decrease with age. The fact that the baseline economy matches reasonably well the decline in the growth rate of employment with age suggests that the model is not exaggerating the impact of financial frictions on firm growth.

Figure 2: Employment growth by age in the model and the data.

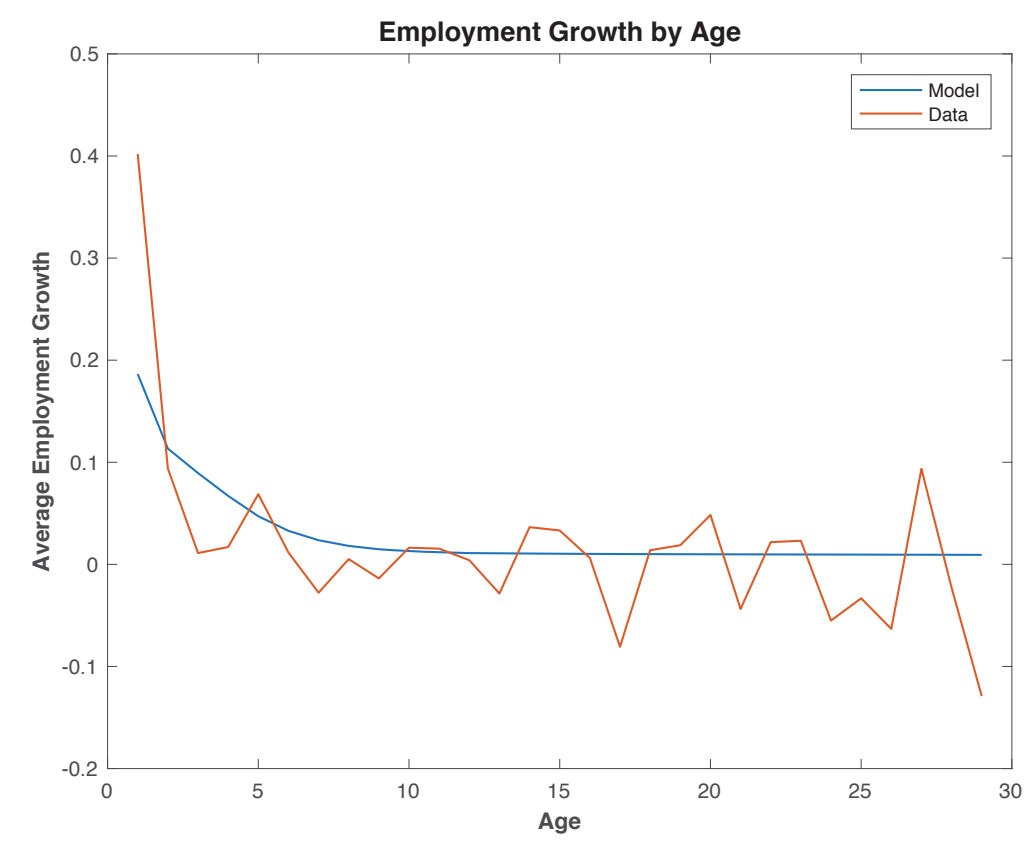

Average employment growth by age. Blue line is data generated from the model, orange line is data from Compustat, where age is computed in the as years since IPO (see online appendix B.1).

\subsection{Aggregate effects of reforming the taxation of capital income}

We now consider the long run effects of a tax reform that eliminates the taxation of corporate income while keeping constant the tax revenue. This is done by finding the common tax rate $(\tau)$ on all forms of capital income (dividends $\tau_{d}$, interest income $\tau_{r}$, and capital gains $\tau_{g}$ ) that collects the same tax revenue as in the baseline economy ${ }^{22}$. The purpose of the proposed policy reform is twofold. Firstly, by equating the three tax rates, all forms of capital income are treated symmetrically from the household perspective. Secondly, by eliminating the corporate tax, financially constrained firms can accumulate profits and reach maturity (the dividend distribution stage) faster (in expectations).

We emphasize that the key insights from our simple model apply to the current stochastic model. Financial frictions imply that firms start their life constrained. For fixed productivity, firms build internal equity over time, becoming less constrained and eventually start distributing dividends. Stochastic shocks imply that firms distributing dividends might be-

\footnotetext{
${ }^{22}$ The tax rate on wages $\tau_{w}$ is kept fixed in all the experiments
} 
come liquidity constrained again if their productivity grows sufficiently over time, so that the "life cycle process" is initiated again. By reducing the corporate tax and increasing the dividend tax, our proposed tax reforms intend to shift the tax burden from liquidity constrained firms (with high marginal valuation of capital) to firms distributing dividends (with low marginal valuation of capital). However, the effects of the reform are more involved than it seems at first sight. This is because firms react to higher dividend taxes by diminishing initial equity, raising the likelihood that firms become liquidity constrained, and (partly) reversing the gains pursued with the elimination of corporate income taxation (see Section $2.4)^{23}$. To minimize these effects, our proposed tax reform involves raising capital gains taxes together with dividend taxes. The rise in capital gains taxes encourages firms to issue more equity in order to minimize taxes paid on capital gains, (partly) undoing the distortions of dividend taxation on initial equity decisions (see discussion in Section 2.4).

To check for potential non-linearities in the responses to tax changes, a tax reform that reduces the tax rate on corporate income to 0.21 is also considered. This experiment is also of interest since in 2017, the US corporate income tax rate was reduced to 0.21 . To isolate the role of capital gains taxation from dividend taxation, we consider a tax reform that sets the corporate income tax rate to 0.21 while keeping the other tax rates at their value in the baseline economy. In this experiment, the dividend tax rate is raised to keep the government budget balanced. Finally, we consider a fourth tax reform in which the investment at entry is subsidized at the rate at which dividends are taxed. In order to evaluate the importance of entry for understanding tax responses, we also perform all the tax reforms in an economy in which entry is kept fixed at its value in the baseline economy ${ }^{24}$.

As further sensitivity analysis, online appendix D.1 considers economies in which the cost of entry rises proportionally (or more than proportionally) to the wage rate ${ }^{25}$. Online appendix D.2 studies the sensitivity of the results when the representative household is allowed to choose labor hours (rather than being fixed as in the baseline economy).

\section{Tax reform 1: Elimination of corporate income taxes}

The results are shown on Table 4 . The elimination of the corporate income taxes in the baseline economy $\left(\tau_{c}=0.34\right)$ should be accompanied by an increase in capital income taxes to 0.41 to keep government revenue constant (recall that in the baseline economy the dividend and capital gains tax was set to 0.15 and the interest income tax was set to 0.25$)$. This revenue neutral tax reform leads to an increase in aggregate output of $12.2 \%$, which is accompanied by a large increase in the aggregate capital stock $(31.8 \%)$, in the number of

\footnotetext{
${ }^{23}$ By financing a larger fraction of investments with internal funds, they reduce the cost of capital.

${ }^{24}$ This is done by fixing the mass of firms to that of the baseline, and finding wages from the labor market clearing condition.

${ }^{25}$ The cost of entry depends on the wage rate: $c_{e}=\bar{c}_{e} w^{\phi}$, where the parameter $\phi$ determines the elasticity of entry costs to wage changes. The baseline economy implicitly assumes $\phi=0$. Online appendix D.1 considers alternative economies with $\phi=1$ and $\phi=2$.
} 
Table 4: Effects of Tax Reforms

\begin{tabular}{llllllllll}
\hline Y & K & TFP & $M_{e}$ & Wage & $\begin{array}{l}\text { Value } \\
\text { entr. }\end{array}$ & $\begin{array}{l}\text { Value } \\
\text { incu. }\end{array}$ & $k_{0}$ & $\mathrm{k}$ & $\tau$ \\
\hline
\end{tabular}

Tax Reform 1: $\tau_{c}=0$; financed by raising $\tau_{d}=\tau_{g}=\tau_{r}$

\begin{tabular}{lcccccccccc}
\hline Baseline & 12.2 & 31.8 & 4.6 & 34.5 & 12.2 & 1.2 & -0.8 & 5.5 & -2.1 & 0.41 \\
No entry & 3.7 & 15.4 & 0.0 & 0.0 & 3.7 & 16.3 & 15.6 & 19.3 & 15.4 & 0.48
\end{tabular}

Tax Reform 2: $\tau_{c}=0.21$; financed by raising $\tau_{d}=\tau_{g}=\tau_{r}$

\begin{tabular}{lcccccccccc}
\hline Baseline & 6.0 & 14.8 & 2.3 & 16.4 & 6.0 & 0.3 & -0.7 & 1.3 & -1.4 & 0.26 \\
No entry & 1.9 & 7.5 & 0.0 & 0.0 & 1.9 & 7.5 & 7.7 & 6.3 & 7.5 & 0.31
\end{tabular}

Tax Reform 3: $\tau_{c}=0.21$; financed by raising $\tau_{d}$

\begin{tabular}{lcccccccccc}
\hline Baseline & -1.2 & 10.0 & -3.6 & -19.1 & -1.2 & -1.9 & 5.0 & -9.1 & 36.0 & 0.39 \\
No entry & 3.4 & 15.7 & -0.4 & 0.0 & 3.4 & -5.3 & -2.1 & -8.9 & 15.7 & 0.32
\end{tabular}

Tax Reform 4: $\tau_{c}=0.21$, financed by $\tau_{d}$, including a subsidy to entry $\tau$

\begin{tabular}{lcccccccccc}
\hline Baseline & 6.3 & 20.4 & 1.4 & 9.7 & 6.3 & 18.0 & -6.1 & 137.3 & 9.8 & 0.29 \\
No Entry & 4.1 & 17.6 & -0.2 & 0.0 & 4.1 & 20.0 & -3.6 & 141.2 & 17.6 & 0.32 \\
\hline
\end{tabular}

Percent changes from the baseline. From left to right: aggregate production (Y), aggregate capital (K), aggregate TFP (TFP), mass of entrants $\left(M_{e}\right)$, average value of entrants gross of initial equity payment (Value entr.), average value of incumbents (Value incu.), average capital at entry $\left(k_{0}\right)$ and average capital $(k)$. In each experiment, we decrease corporate tax, but change other taxes $\tau$ such that the government revenue is constant. $\tau$ corresponds to the value of the tax rate being changed, specified in each line.

firms $(34.5 \%)$, and in aggregate TFP (4.6\%). Note that the fact that aggregate capital and output rise less than the number of firms, indicates that both capital per firm and output per firm decrease (by $2 \%$ and $17 \%$, respectively). Hence, the response of firm entry to the tax reform is crucial for the large increase in aggregate output and aggregate TFP in the baseline economy. When entry is kept fixed at the value in the baseline economy, aggregate output increases by $3.7 \%$ and capital by $15.4 \%$. Hence, the increase in output is about a third the one in the baseline economy and the increase in capital is about half. Note that output per firm and capital per firm rise since the number of firms is kept constant ${ }^{26}$.

Crucially for our results, in our baseline economy the tax reform increases the expected value of entry more than the value of incumbent firms, which leads to a reallocation of resources from mature to young firms, and hence to an increase in entry and in the equilibrium wage rate. Note that corporate income taxation has asymmetric effects across firms depending on their financial regime. The elimination of corporate income taxation allows financially constrained firms to retain a larger fraction of their earnings and increase their

\footnotetext{
${ }^{26}$ Given the importance of entry for our results, online appendix D.1 reports the effects of tax reforms in two new model economies that vary in the response of entry to tax changes.
} 
investments. The ability to retain earnings is particularly relevant for young firms, which are more likely to be constrained than the average incumbent firm in the economy. The value of entry is determined by the average value of age- 0 firms. This observation explains why, keeping the wage of the baseline economy fixed, the value of the average firm entering the economy increases more than that of incumbent firms (60\% versus $54 \%$ ) with the elimination of corporate income taxes. In general equilibrium, the increase in the value of entry requires the wage rate to rise by about $12.2 \%$ in order to restore the free entry condition. The rise in the wage rate reduces the value of incumbent firms (by 0.8\%) and aggregate labor demand. Hence, firm entry rises (by 34.5\%) in order to clear the labor market. When the number of firms is kept fixed, the wage rate rises by a more modest amount (3.7\% instead of 12.2\%) for the labor market to clear. The average firm is $15.4 \%$ larger.

Summing up, we find that in general equilibrium the elimination of corporate income tax shifts resources from old to young businesses, decreasing the market value of incumbent firms relative to entrants. The equilibrium wage rate and business entry rise. The response of entry is crucial for the large increase in aggregate output and TFP.

\section{Tax reform 2: $\tau_{c}=0.21$ and increase all other capital income taxes}

The corporate income tax rate is set as $\tau_{c}=0.21$ while all other capital income taxes are set to $0.26\left(\tau_{g}=\tau_{d}=\tau_{r}=0.26\right)$. The reduction in the corporate tax rate is about $40 \%$ of the one in the previous experiment (0.13 percentage point decrease instead of 0.34 ). We find that output increases by $6.0 \%$ and entry increases by $16 \%$ (see Table 4 ). These magnitues are about half the ones obtained when the corporate income taxation was eliminated $(12.2 \%$ increase in output and $34.5 \%$ increase in entry). Hence, the effects on output and entry of reducing the taxation of corporate income are non-linear but not too far from linearity.

\section{Tax reform 3: $\tau_{c}=0.21$ and only increase dividend tax}

The corporate income tax rate is set as $\tau_{c}=0.21$ and the dividend tax rate is set to $\tau_{d}=0.39$ to balance the governnment budget constraint. The tax rates on capital gains and on interest income are kept fixed at their values in the baseline economy. The results in Table 4 show that output decreases by $1.2 \%$. Recall that the previous reform (which sets the corporate income tax to 0.21 while equating the tax rates on dividends and capital gains) lead to an output gain of $6 \%$. Hence, the output gains of equating the tax rates on capital gains and dividends are substantial. Why is this the case? When $\tau_{g}$ is substantially below $\tau_{d}$, firms have strong incentives to accumulate capital internally (see the discussion in Section 2.4). As a result, firms enter the economy with a small size. The average initial equity is reduced by 9\% relative to the baseline economy (while in Tax Reform 2 it is slightly higher than in the baseline economy). Firms take more time to grow which reduces the value of entrants. As a result, relative to the baseline economy, entry is reduced by $19 \%$. The fact that aggregate 
capital rises by $10 \%$ while the number of firm decreases implies that the average firm is much bigger than in the baseline economy (36\% in terms of capital and $24 \%$ in terms of labor). When the dividend tax is higher than the capital gains tax, the tax code makes equity financing more costly than financing with retained earnings, thereby hurting young firms and entry, favoring investment by incumbent firms and leading to an increase in the average business size. In the next tax reform, we show that these effects can be (partially) reversed if the high dividend tax (relative to the capital gains tax) is compensated with a subsidy to initial equity issuance.

\section{Tax reform 4: $\tau_{c}=0.21$, increase dividend tax and introduce a subsidy to entry}

The results from the last experiment point to the importance of equating the tax rate on capital gains and dividends. If the wedge between the dividend tax rate and the capital gains tax rate is large, firms invest too little when they enter and financial frictions have more negative effects on firm growth. One concern is that capital gains in the US are taxed upon realization, while in the model economy they are taxed on an accrual basis. Since the realization of capital gains is an endogenous decision, the model economy might be overstating the effects of capital gains taxation. Therefore, we consider the following variation of the previous tax reform: the reduction of the corporate income tax rate to 0.21 is accompanied by a subsidy to initial equity issuance. The dividend tax rate is set to balance the government budget constraint, and the subsidy to initial equity is set to $\tau_{d}$. Hence, equation (31) now reads:

$$
\hat{k}_{0}\left(z_{0}\right)=k_{k_{0}}\left\{v\left(z_{0}, k_{0}\right)-\left(\frac{1}{(1-\xi)}-\tau_{d}\right) k_{0}\right\} .
$$

The purpose of this tax reform is to treat symmetrically investment financed with retained earnings or with equity issuance. In the presence of a dividend tax, the government is effectively sharing a fraction $\tau_{d}$ of the investment costs of mature firms. Then, by subsidizing initial equity issuance at a rate $\tau_{d}$ the government is treating symmetrically investment by new firms and incumbent (mature) firms. This reform leads to an increase in output of $6.3 \%$, which is similar to the one obtained under Tax Reform 2. The key difference between these reforms is that the average firm size increases by $9.8 \%$ under tax reform 4 and decreases by $1.4 \%$ under tax reform 2 . The higher average firm size under tax reform 4 is due to a larger firm size both at entry and at maturity (see (19)). Entry is less responsive under tax reform 4 than tax reform 2, despite the fact that the former reform directly subsidizes entry. This paradoxical observation is explained by the fact that the equilibrium mass of entry is determined to clear the labor market. Since the average firm is larger under tax reform 4 than tax reform 2, entry is lower in the former case. 


\subsubsection{Taxation and the life cycle of firms}

It is interesting to compare the average life cycle behavior of firms across the model economies. Panel A of Figure 3 shows the average equity to investment ratio for the baseline economy and the economies with the Tax Reforms 2, 3 and 4. When the capital gains tax is smaller than the dividend tax (Tax Reform 3), firms are much more reluctant to finance investment with equity issuance. Moreover, as shown in Panel B of the same figure, firms distribute

Figure 3: Life Cycle of Firms

A: Equity to Investment by Age

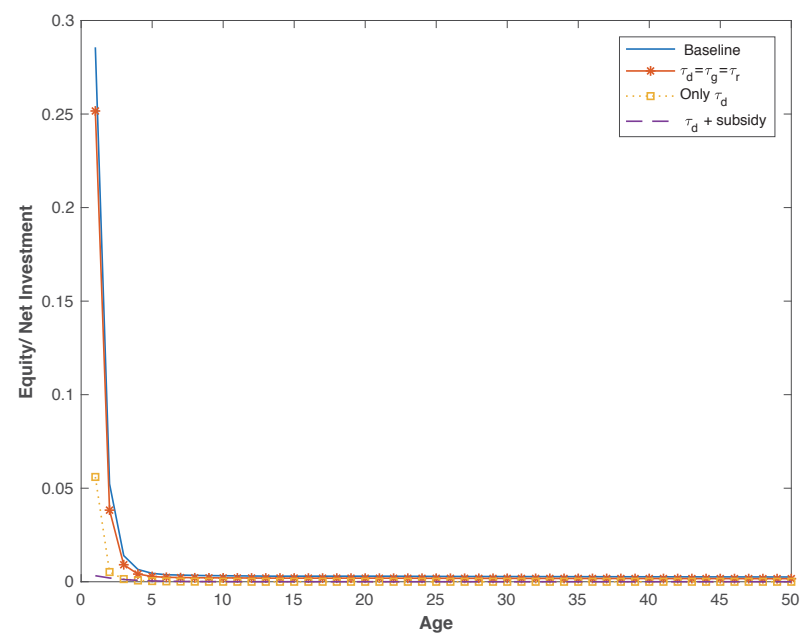

C: Employment Growth by Age

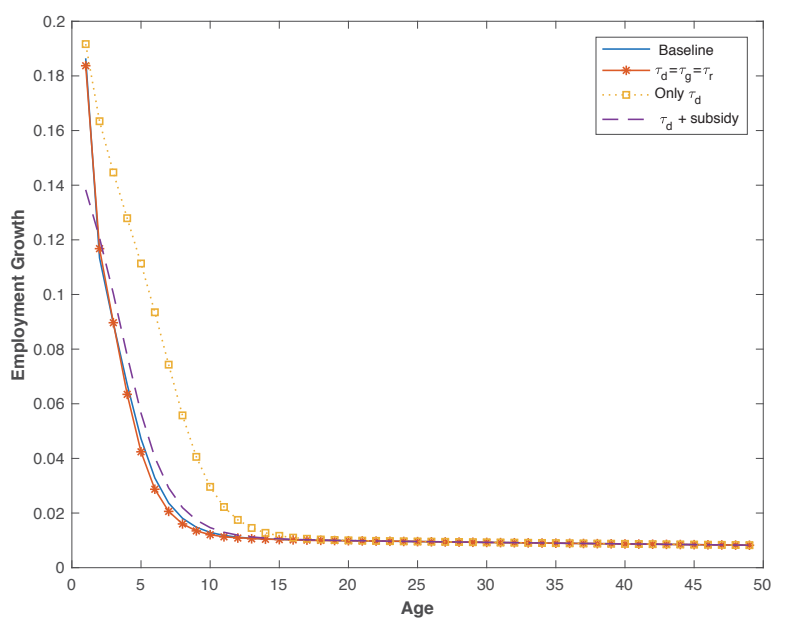

B: Dividends to Earnings by Age

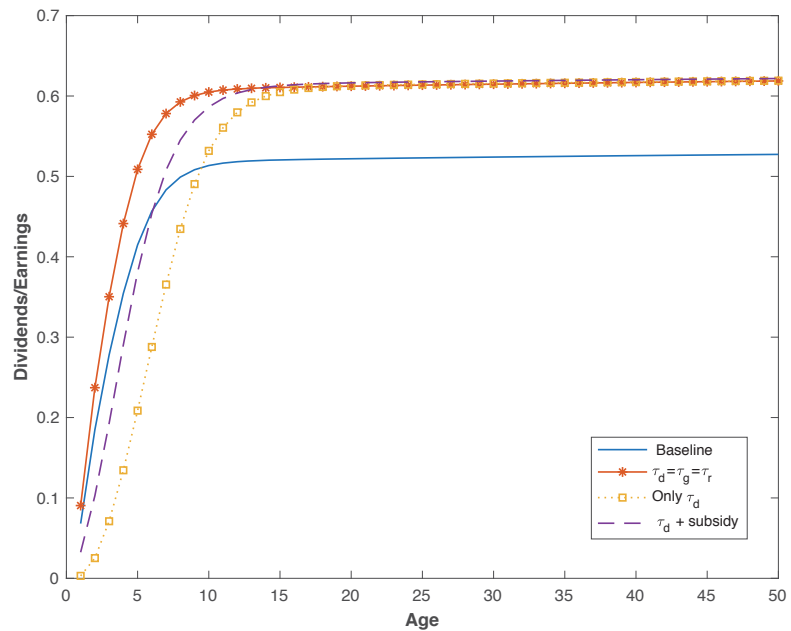

D: Average Capital by Age

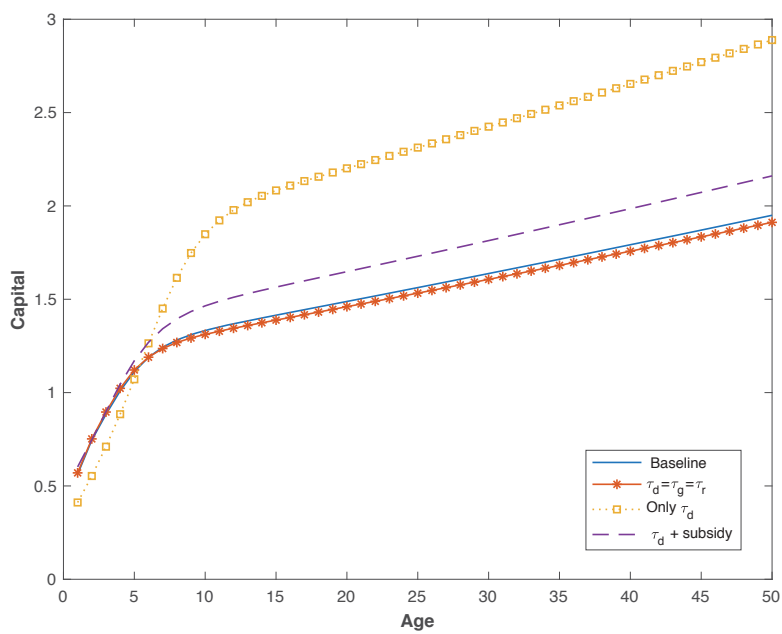

Average age profiles for equity to investment, dividends to earnings, employment growth and capital. Blue solid line (Baseline) corresponds to the baseline calibration. Starred orange line $\left(\tau_{d}=\tau_{g}=\tau_{r}\right)$ corresponds to Tax Reform 2, i.e. $\tau_{c}=0.21$, and $\tau_{d}=\tau_{g}=\tau_{r}=0.26$ to keep the governement budget constraint balanced. Dotted yellow line (Only $\tau_{d}$ ) corresponds to Tax Reform 3, i.e. $\tau_{c}=0.21$, and $\tau_{d}=0.39$ to keep the governement budget constraint balanced, while the other taxes are set to their baseline values $\left(\tau_{g}=0.15, \tau_{r}=0.25\right)$. Dashed purple line $\left(\tau_{d}+\right.$ subsidy $)$ corresponds to Tax Reform 4, i.e. $\tau_{c}=0.21$, $\tau_{d}=0.29$ and a subsidy to entry equal to $\tau_{d}$ financed by the government, maintaining the governement budget constraint balanced, while the other taxes are set to their baseline values $\left(\tau_{g}=0.15, \tau_{r}=0.25\right)$. 
much fewer dividends when young in Tax Reform 3 because they are (slowly) building internal equity. In Tax Reform 4, firms do not issue much equity, since they start while already big, but the time it takes them to reach maturity is longer than under Tax Reform 2, because their optimal size is larger. Nonetheless, when firms mature there are no differences in the dividends to earnings ratio under the Tax Reforms 2, 3 and 4. Mature firms in the baseline economy distribute a lower fraction of their earnings because they are paying higher corporate taxes than in the other two economies. Panel $\mathrm{C}$ of Figure 3 shows that the mean employment growth rate of firms is much higher under Tax Reform 3. Again, when capital gains taxes are lower than dividend taxes, firms start small and grow fast by retarding dividend payments and accumulating internal equity. Since firms discount future payouts at a low rate when capital gains taxes are low, they have a strong incentive to grow over their life cycle. Even though the average firm size at entry is smallest under Tax Reform 3, the average size late in the life cycle is the largest across all economies (see Panel D). The large dispersion in business size over the life cycle and the low entry under Tax Reform 3 explains why this economy features the lowest TFP among all the economies considered. Note that in Tax Reform 4, average size is larger than in Tax Reform 2 since capital gains taxes, which distort optimal size, are maintained at the baseline level while decreasing coporate taxes.

\section{Conclusions}

In this paper, we use a model of firm dynamics with endogenous entry to analyze the impact of different forms of taxing capital income on investment over the life cycle of firms and on firm entry. We use the calibrated model economy to quantitatively assess the effects of a reform that eliminates the taxation of corporate income while keeping constant the tax revenue collected on capital. This is done by finding the common tax rate $(\tau)$ on all forms of capital income (dividends $\tau_{d}$, interest income $\tau_{r}$, and capital gains $\tau_{g}$ ) that collects the same tax revenue as in the baseline economy. The purpose of the proposed policy reform is twofold. Firstly, by equating the three tax rates, we would be treating symmetrically all forms of capital income from the household perspective. Secondly, by eliminating the corporate tax, financially constrained firms can accumulate profits and reach maturity (the dividend distribution stage) faster. This revenue neutral tax reform leads to an increase in aggregate output of $12.2 \%$, which is accompanied by a large increase in the aggregate capital stock $(31.8 \%)$ and in the number of firms (34.5\%). Note that the fact that aggregate capital and output rise less than the number of firms indicates that the average size of the firm is smaller after the tax reform. Hence, it is the large response of firm entry to the tax reform that drives the large increase in aggregate output and capital.

At the heart of our results is the fact that the tax reform increases the expected value of entry more than the value of incumbent firms, leading to a reallocation of resources from mature to younger firms that operates through an increase in entry and in the equilibrium 
wage rate. The elimination of corporate income taxation allows financially constrained firms to retain a larger fraction of their earnings and increase their investments. The ability to retain earnings is particularly relevant for young firms, which are more likely to be constrained than the average incumbent firm in the economy. Since the value of entry is determined by the average value of age- 0 firms, the value of the average firm entering the economy increases more than that of incumbent firms when corporate income taxation is eliminated. In general equilibrium, the increase in the value of entry requires the wage rate to rise, which reduces labor demand by incumbent firms. Labor market clearing requires a larger mass of firm entry. Larger firm entry together with a reallocation of resources to financially constrained firms lead to an increase in aggregate TFP of $4.6 \%$.

Our paper abstracts from many effects of corporate income taxation. In particular, the corporate income is likely to affect the organizational form of firms, the incentives of firms to borrow and to invest in intangible capital. While these issues are out of the scope of the current paper, they are important for having a complete assessment of the impact of corporate income taxation. 


\section{References}

Achdou, Y., Han, J., Lasry, J.M., Lions, P.L., Moll, B., 2017. Income and wealth distribution in macroeconomics: A continuous-time approach. Technical Report. National Bureau of Economic Research.

Anagnostopoulos, A., Atesagaoglu, O.E., Carceles-Poveda, E., 2015. On the double taxation of corporate profits. Available at SSRN URL: https://ssrn.com/abstract= 2496524 orhttp://dx.doi.org/10.2139/ssrn. 2496524.

Asker, J., Farre-Mensa, J., Ljungqvist, A., 2011. What do private firms look like? URL: https://ssrn. com/abstract=1659926orhttp://dx.doi.org/10.2139/ssrn. 1659926.

Atesagaoglu, O.E., 2012. Taxes, regulations and the corporate debt market. International Economic Review 53, 979-1004.

Atkeson, A., Kehoe, P.J., 2005. Modeling and measuring organization capital. Journal of Political Economy 113, 1026-1053.

Auerbach, A.J., 2002. Taxation and corporate financial policy, in: Handbook of public economics. Elsevier. volume 3, pp. 1251-1292.

Auerbach, A.J., Hassett, K.A., 2007. The 2003 dividend tax cuts and the value of the firm: An event study, in: Taxing Corporate Income in the 21st Century.

Barczyk, D., Kredler, M., 2014. Altruistically motivated transfers under uncertainty. Quantitative Economics 5, 705-749.

Becker, B., Jacob, M., Jacob, M., 2013. Payout taxes and the allocation of investment. Journal of Financial Economics 107, 1-24.

Campbell, J.L., Chyz, J.A., Dhaliwal, D.S., Schwartz Jr, W.C., 2013. Did the 2003 tax act increase capital investments by corporations? The Journal of the American Taxation Association 35, 33-63.

Cloyne, J., Ferreira, C., Froemel, M., Surico, P., 2018. Investment, financial frictions and the dynamic effects of monetary policy. Working paper .

Conesa, J.C., Domínguez, B., 2013. Intangible investment and ramsey capital taxation. Journal of Monetary Economics 60, 983-995.

Cooley, T.F., Prescott, E.C., 1995. Economic growth and business cycles. Frontiers of business cycle research 1 .

Cooley, T.F., Quadrini, V., 2001. Financial markets and firm dynamics. American Economic Review 91, 1286-1310. 
Cooper, R.W., Haltiwanger, J.C., 2006. On the nature of capital adjustment costs. The Review of Economic Studies 73, 611-633.

Da-Rocha, J.M., Tavares, M.M., Restuccia, D., 2017. Policy distortions and aggregate productivity with endogenous establishment-level productivity. Technical Report. National Bureau of Economic Research.

Dyrda, S., Pugsley, B., 2018. Taxes, private equity, and evolution of income inequality in the us .

Gabaix, X., 2009. Power laws in economics and finance. Annu. Rev. Econ. 1, 255-294.

Gomes, J.F., 2001. Financing investment. American Economic Review 91, 1263-1285.

Gourio, F., Miao, J., 2010. Firm heterogeneity and the long-run effects of dividend tax reform. American Economic Journal: Macroeconomics 2, 131-68.

Hall, B.H., 1987. The relationship between firm size and firm growth in the us manufacturing sector. The Journal of Industrial Economics 35, 583-606.

Haltiwanger, J., 2006. Entrepreneurship and job growth. Available at SSRN URL: https:// ssrn. com/abstract=1244668orhttp://dx.doi.org/10.2139/ssrn. 1244668.

Haltiwanger, J., Jarmin, R.S., Miranda, J., 2013. Who creates jobs? small versus large versus young. Review of Economics and Statistics 95, 347-361.

Hennessy, C.A., Whited, T.M., 2007. How costly is external financing? evidence from a structural estimation. The Journal of Finance 62, 1705-1745.

Hopenhayn, H., Rogerson, R., 1993. Job turnover and policy evaluation: A general equilibrium analysis. Journal of political Economy 101, 915-938.

Hsieh, C.T., Klenow, P.J., 2009. Misallocation and manufacturing tfp in china and india. The Quarterly journal of economics 124, 1403-1448.

Jermann, U., Quadrini, V., 2012. Macroeconomic effects of financial shocks. American Economic Review 102, 238-71.

Kari, S., Karikallio, H., Pirttila, J., 2009. The impact of dividend taxation on dividends and investment: New evidence based on a natural experiment .

Khan, A., Thomas, J.K., 2013. Credit shocks and aggregate fluctuations in an economy with production heterogeneity. Journal of Political Economy 121, 1055-1107.

Korinek, A., Stiglitz, J.E., 2009. Dividend taxation and intertemporal tax arbitrage. Journal of Public Economics 93, 142-159. 
Lee, I., Lochhead, S., Ritter, J., Zhao, Q., 1996. The costs of raising capital. Journal of Financial Research 19, 59-74.

Luttmer, E.G., 2007. Selection, growth, and the size distribution of firms. The Quarterly Journal of Economics 122, 1103-1144.

McGrattan, E.R., Prescott, E.C., 2005. Taxes, regulations, and the value of us and uk corporations. The Review of Economic Studies 72, 767-796.

Midrigan, V., Xu, D.Y., 2014. Finance and misallocation: Evidence from plant-level data. American economic review 104, 422-58.

Poterba, J., Summers, L., 1985. The economic effects of dividend taxation. E. Altman and M. Subrahmanyam, eds., Recent Advances in Corporation Finance (Homewood,IL: Dow Jones-Irwin) 104, 227-284. 


\title{
BANCO DE ESPAÑA PUBLICATIONS
}

\author{
WORKING PAPERS
}

1840 ALESSIO MORO and OMAR RACHEDI: The changing structure of government consumption spending.

1841 GERGELY GANICS, ATSUSHI INOUE and BARBARA ROSSI: Confidence intervals for bias and size distortion in IV and local projections - IV models.

1842 MARÍA GIL, JAVIER J. PÉREZ, A. JESÚS SÁNCHEZ and ALBERTO URTASUN: Nowcasting private consumption: traditional indicators, uncertainty measures, credit cards and some internet data.

1843 MATÍAS LAMAS and JAVIER MENCÍA: What drives sovereign debt portfolios of banks in a crisis context?

1844 MIGUEL ALMUNIA, POL ANTRÀS, DAVID LÓPEZ-RODRÍGUEZ and EDUARDO MORALES: Venting out: exports during a domestic slump.

1845 LUCA FORNARO and FEDERICA ROMEI: The paradox of global thrift.

1846 JUAN S. MORA-SANGUINETTI and MARTA MARTÍNEZ-MATUTE: An economic analysis of court fees: evidence from the Spanish civil jurisdiction.

1847 MIKEL BEDAYO, ÁNGEL ESTRADA and JESÚS SAURINA: Bank capital, lending booms, and busts. Evidence from Spain in the last 150 years.

1848 DANIEL DEJUÁN and CORINNA GHIRELLI: Policy uncertainty and investment in Spain.

1849 CRISTINA BARCELÓ and ERNESTO VILLANUEVA: The risk of job loss, household formation and housing demand: evidence from differences in severance payments.

1850 FEDERICO TAGLIATI: Welfare effects of an in-kind transfer program: evidence from Mexico.

1851 ÓSCAR ARCE, GALO NUÑO, DOMINIK THALER and CARLOS THOMAS: A large central bank balance sheet? Floor vs corridor systems in a New Keynesian environment.

1901 EDUARDO GUTIÉRREZ and ENRIQUE MORAL-BENITO: Trade and credit: revisiting the evidence.

1902 LAURENT CAVENAILE and PAU ROLDAN: Advertising, innovation and economic growth.

1903 DESISLAVA C. ANDREEVA and MIGUEL GARCÍA-POSADA: The impact of the ECB's targeted long-term refinancing operations on banks' lending policies: the role of competition.

1904 ANDREA ALBANESE, CORINNA GHIRELLI and MATTEO PICCHIO: Timed to say goodbye: does unemployment benefit eligibility affect worker layoffs?

1905 CORINNA GHIRELLI, MARÍA GIL, JAVIER J. PÉREZ and ALBERTO URTASUN: Measuring economic and economic policy uncertainty, and their macroeconomic effects: the case of Spain.

1906 CORINNA GHIRELLI, JAVIER J. PÉREZ and ALBERTO URTASUN: A new economic policy uncertainty index for Spain.

1907 ESTEBAN GARCÍA-MIRALLES, NEZIH GUNER and ROBERTO RAMOS: The Spanish personal income tax: facts and parametric estimates.

1908 SERGIO MAYORDOMO and OMAR RACHEDI: The China syndrome affects banks: the credit supply channel of foreign import competition.

1909 MÓNICA CORREA-LÓPEZ, MATÍAS PACCE and KATHI SCHLEPPER: Exploring trend inflation dynamics in Euro Area countries.

1910 JAMES COSTAIN, ANTON NAKOV and BORJA PETIT: Monetary policy implications of state-dependent prices and wages.

1911 JAMES CLOYNE, CLODOMIRO FERREIRA, MAREN FROEMEL and PAOLO SURICO: Monetary policy, corporate finance and investment.

1912 CHRISTIAN CASTRO and JORGE E. GALÁN: Drivers of productivity in the Spanish banking sector: recent evidence.

1913 SUSANA PÁRRAGA RODRÍGUEZ: The effects of pension-related policies on household spending.

1914 MÁXIMO CAMACHO, MARÍA DOLORES GADEA and ANA GÓMEZ LOSCOS: A new approach to dating the reference cycle.

1915 LAURA HOSPIDO, LUC LAEVEN and ANA LAMO: The gender promotion gap: evidence from Central Banking.

1916 PABLO AGUILAR, STEPHAN FAHR, EDDIE GERBA and SAMUEL HURTADO: Quest for robust optimal macroprudential policy.

1917 CARMEN BROTO and MATÍAS LAMAS: Is market liquidity less resilient after the financial crisis? Evidence for US treasuries.

1918 LAURA HOSPIDO and CARLOS SANZ: Gender Gaps in the Evaluation of Research: Evidence from Submissions to Economics Conferences.

1919 SAKI BIGIO, GALO NUÑO and JUAN PASSADORE: A framework for debt-maturity management.

1920 LUIS J. ÁLVAREZ, MARÍA DOLORES GADEA and ANA GÓMEZ-LOSCOS: Inflation interdependence in advanced economies. 
1921 DIEGO BODAS, JUAN R. GARCÍA LÓPEZ, JUAN MURILLO ARIAS, MATÍAS J. PACCE, TOMASA RODRIGO LÓPEZ, JUAN DE DIOS ROMERO PALOP, PEP RUIZ DE AGUIRRE, CAMILO A. ULLOA and HERIBERT VALERO LAPAZ: Measuring retail trade using card transactional data.

1922 MARIO ALLOZA and CARLOS SANZ: Jobs multipliers: evidence from a large fiscal stimulus in Spain.

1923 KATARZYNA BUDNIK, MASSIMILIANO AFFINITO, GAIA BARBIC, SAIFFEDINE BEN HADJ, ÉDOUARD CHRÉTIEN, HANS DEWACHTER, CLARA ISABEL GONZÁLEZ, JENNY HU, LAURI JANTUNEN, RAMONA JIMBOREAN, OTSO MANNINEN, RICARDO MARTINHO, JAVIER MENCÍA, ELENA MOUSARRI, LAURYNAS NARUŠEVIČIUS, GIULIO NICOLETTI, MICHAEL O'GRADY, SELCUK OZSAHIN, ANA REGINA PEREIRA, JAIRO RIVERA-ROZO, CONSTANTINOS TRIKOUPIS, FABRIZIO VENDITTI and SOFÍA VELASCO: The benefits and costs of adjusting bank capitalisation: evidence from Euro Area countries.

1924 MIGUEL ALMUNIA and DAVID LÓPEZ-RODRÍGUEZ: The elasticity of taxable income in Spain: 1999-2014.

1925 DANILO LEIVA-LEON and LORENZO DUCTOR: Fluctuations in global macro volatility.

1926 JEF BOECKX, MAARTEN DOSSCHE, ALESSANDRO GALESI, BORIS HOFMANN and GERT PEERSMAN: Do SVARs with sign restrictions not identify unconventional monetary policy shocks?

1927 DANIEL DEJUÁN and JUAN S. MORA-SANGUINETTI: Quality of enforcement and investment decisions. Firm-level evidence from Spain.

1928 MARIO IZQUIERDO, ENRIQUE MORAL-BENITO and ELVIRA PRADES: Propagation of sector-specific shocks within Spain and other countries.

1929 MIGUEL CASARES, LUCA DEIDDA and JOSÉ E. GALDÓN-SÁNCHEZ: On financial frictions and firm market power.

1930 MICHAEL FUNKE, DANILO LEIVA-LEON and ANDREW TSANG: Mapping China's time-varying house price landscape.

1931 JORGE E. GALÁN and MATÍAS LAMAS: Beyond the LTV ratio: new macroprudential lessons from Spain.

1932 JACOPO TIMINI: Staying dry on Spanish wine: the rejection of the 1905 Spanish-Italian trade agreement.

1933 TERESA SASTRE and LAURA HERAS RECUERO: Domestic and foreign investment in advanced economies. The role of industry integration.

1934 DANILO LEIVA-LEON, JAIME MARTÍNEZ-MARTÍN and EVA ORTEGA: Exchange rate shocks and inflation comovement in the euro area.

1935 FEDERICO TAGLIATI: Child labor under cash and in-kind transfers: evidence from rural Mexico.

1936 ALBERTO FUERTES: External adjustment with a common currency: the case of the euro area.

1937 LAURA HERAS RECUERO and ROBERTO PASCUAL GONZÁLEZ: Economic growth, institutional quality and financial development in middle-income countries.

1938 SILVIA ALBRIZIO, SANGYUP CHOI, DAVIDE FURCERI and CHANSIK YOON: International Bank Lending Channel of Monetary Policy.

1939 MAR DELGADO-TÉLLEZ, ENRIQUE MORAL-BENITO and JAVIER J. PÉREZ: Outsourcing and public expenditure: an aggregate perspective with regional data.

1940 MYROSLAV PIDKUYKO: Heterogeneous spillovers of housing credit policy.

1941 LAURA ÁLVAREZ ROMÁN and MIGUEL GARCÍA-POSADA GÓMEZ: Modelling regional housing prices in Spain.

1942 STÉPHANE DÉES and ALESSANDRO GALESI: The Global Financial Cycle and US monetary policy in an interconnected world.

1943 ANDRÉS EROSA and BEATRIZ GONZÁLEZ: Taxation and the life cycle of firms.

BANCODEESPAÑA Eurosistema
Unidad de Servicios Auxiliares

Alcalá, 48 - 28014 Madrid

E-mail: publicaciones@bde.es www.bde.es 